\title{
THE
}

\section{The contribution of the Weddell Gyre to the lower limb of the Global Overturning Circulation}

Loïc Jullion

Alberto C. Naveira Garabato

Sheldon Bacon

Michael P. Meredith

Pete J. Brown

See next page for additional authors

Follow this and additional works at: https://digitalcommons.uri.edu/gsofacpubs

Terms of Use

All rights reserved under copyright.

\section{Citation/Publisher Attribution}

Jullion, L., et al. (2014), The contribution of the Weddell Gyre to the lower limb of the Global Overturning Circulation, J. Geophys. Res. Oceans, 119, 3357-3377, doi:10.1002/2013JC009725.

Available at: https://doi.org/10.1002/2013JC009725

This Article is brought to you for free and open access by the Graduate School of Oceanography at DigitalCommons@URI. It has been accepted for inclusion in Graduate School of Oceanography Faculty Publications by an authorized administrator of DigitalCommons@URI. For more information, please contact digitalcommons-group@uri.edu. 


\section{Authors}

Loïc Jullion, Alberto C. Naveira Garabato, Sheldon Bacon, Michael P. Meredith, Pete J. Brown, Sinhue Torres-Valdés, Kevin G. Speer, Paul R. Holland, Jun Dong, Dorothée Bakker, Mario Hoppema, Brice Loose, Hugh J. Venables, William J. Jenkins, Marie-José Messias, and Eberhard Fahrbach 


\section{Journal of Geophysical Research: Oceans}

\section{RESEARCH ARTICLE}

10.1002/2013JC009725

Key Points:

- The Weddell Sea hosts a 13 Sv doubled-cell overturning

- The net production of Antarctic Bottom Water in the Weddell Sea is $6 \mathrm{~Sv}$

- The Weddell gyre recycles and exports bottom water formed outside gyre

Supporting Information:

- Figure S1

- Figure S2

- Supplementary text

Correspondence to:

L. Jullion,

ljullion@fsu.edu

Citation:

Jullion, L., et al. (2014), The contribution of the Weddell Gyre to the lower limb of the Global Overturning Circulation, J. Geophys. Res. Oceans, 119, 3357-3377, doi:10.1002/2013JC009725.

Received 11 DEC 2013 Accepted 1 MAY 2014 Accepted article online 5 MAY 2014 Published online 5 JUN 2014

\section{The contribution of the Weddell Gyre to the lower limb of the Global Overturning Circulation}

\author{
Loïc Jullion 1,2, Alberto C. Naveira Garabato', Sheldon Bacon ${ }^{3}$, Michael P. Meredith 4,5, \\ Pete J. Brown ${ }^{4,6}$, Sinhue Torres-Valdés ${ }^{3}$, Kevin G. Speer ${ }^{2}$, Paul R. Holland4 ${ }^{4}$ Jun Dong ${ }^{2}$, \\ Dorothée Bakker6, Mario Hoppema7, Brice Loose ${ }^{8}$, Hugh J. Venables ${ }^{4}$, William J. Jenkins9, \\ Marie-José Messias ${ }^{10}$, and Eberhard Fahrbach7
}

${ }^{1}$ National Oceanography Centre, University of Southampton, Southampton, UK, ${ }^{2}$ Geophysical Fluid Dynamics Institute, Florida State University, Tallahassee, Florida, USA, ${ }^{3}$ National Oceanography Centre, Southampton, UK, ${ }^{4}$ British Antarctic Survey, Cambridge, UK, ${ }^{5}$ Scottish Association for Marine Science, Oban, Argyll, UK, ${ }^{6}$ School of Environmental Sciences, University of East Anglia, Norwich, UK, ${ }^{7}$ Alfred-Wegener-Institut, Bremerhaven, Germany, ${ }^{8}$ Graduate School of Oceanography, University of Rhode Island, Narragansett, Rhode Island, USA, ${ }^{9}$ Woods Hole Oceanographic Institution, Woods Hole, Massachusetts, USA, ${ }^{10}$ School of Geography, University of Exeter, Exeter, UK

\begin{abstract}
The horizontal and vertical circulation of the Weddell Gyre is diagnosed using a box inverse model constructed with recent hydrographic sections and including mobile sea ice and eddy transports. The gyre is found to convey $42 \pm 8 \mathrm{~Sv}(1 \mathrm{~Sv}=106 \mathrm{~m} 3 \mathrm{~s}-1)$ across the central Weddell Sea and to intensify to $54 \pm 15$ Sv further offshore. This circulation injects $36 \pm 13$ TW of heat from the Antarctic Circumpolar Current to the gyre, and exports $51 \pm 23 \mathrm{mSv}$ of freshwater, including $13 \pm 1 \mathrm{mSv}$ as sea ice to the midlatitude Southern Ocean. The gyre's overturning circulation has an asymmetric double-cell structure, in which $13 \pm 4$ Sv of Circumpolar Deep Water (CDW) and relatively light Antarctic Bottom Water (AABW) are transformed into upper-ocean water masses by midgyre upwelling (at a rate of $2 \pm 2 \mathrm{~Sv}$ ) and into denser AABW by downwelling focussed at the western boundary $(8 \pm 2 \mathrm{~Sv})$. The gyre circulation exhibits a substantial throughflow component, by which CDW and AABW enter the gyre from the Indian sector, undergo ventilation and densification within the gyre, and are exported to the South Atlantic across the gyre's northern $\mathrm{rim}$. The relatively modest net production of AABW in the Weddell Gyre $(6 \pm 2 \mathrm{~Sv})$ suggests that the gyre's prominence in the closure of the lower limb of global oceanic overturning stems largely from the recycling and equatorward export of Indian-sourced AABW.
\end{abstract}

\section{Introduction}

The Southern Ocean plays a pivotal role in the global ocean circulation. The absence of continental barriers in the latitude band of Drake Passage permits the existence of the eastward-flowing Antarctic Circumpolar Current (ACC), which is supported geostrophically by sloping isopycnals and serves as a conduit for oceanic exchanges between the three major ocean basins [Rintoul and Naveira Garabato, 2013]. Coupled to this intense zonal flow, a meridional circulation exists in which Circumpolar Deep Water (CDW) upwells along the southward-shoaling isopycnals of the ACC [Speer et al., 2000]. Whereas the lighter classes of CDW reach the upper-ocean mixed layer within the ACC and are returned northward near the surface, the denser classes of CDW are transported southward and enter the system of cyclonic gyres and westward-flowing slope frontal jets encircling Antarctica. There, CDW replenishes and mixes with Antarctic surface waters and water masses found over the Antarctic continental shelves, ultimately resulting in the formation of Antarctic Bottom Water (AABW). The production and northward export of AABW is an integral component of the southern closure of the Global Overturning Circulation (GOC) [Talley, 2013], gives rise to its lower cell [Lumpkin and Speer, 2007], and is an important driver of deep global ocean ventilation [Orsi et al., 2002] and marine biogeochemical cycling [Marinov et al., 2006].

Traditionally, the Weddell Gyre (Figure 1) has been regarded as by far the primary region of AABW formation, accounting for upward of $60-70 \%$ of all AABW production [Orsi et al., 1999, 2002]. Through several decades of oceanographic measurements, a picture of the gyre has been built in which CDW enters the gyre's southern limb near $30^{\circ} \mathrm{E}$ [Orsi and Whitworth, 1993; Gouretski and Danilov, 1993; Park et al., 2001] and is gradually cooled and freshened by mixing with ambient waters as it flows westward near Antarctica. Further 


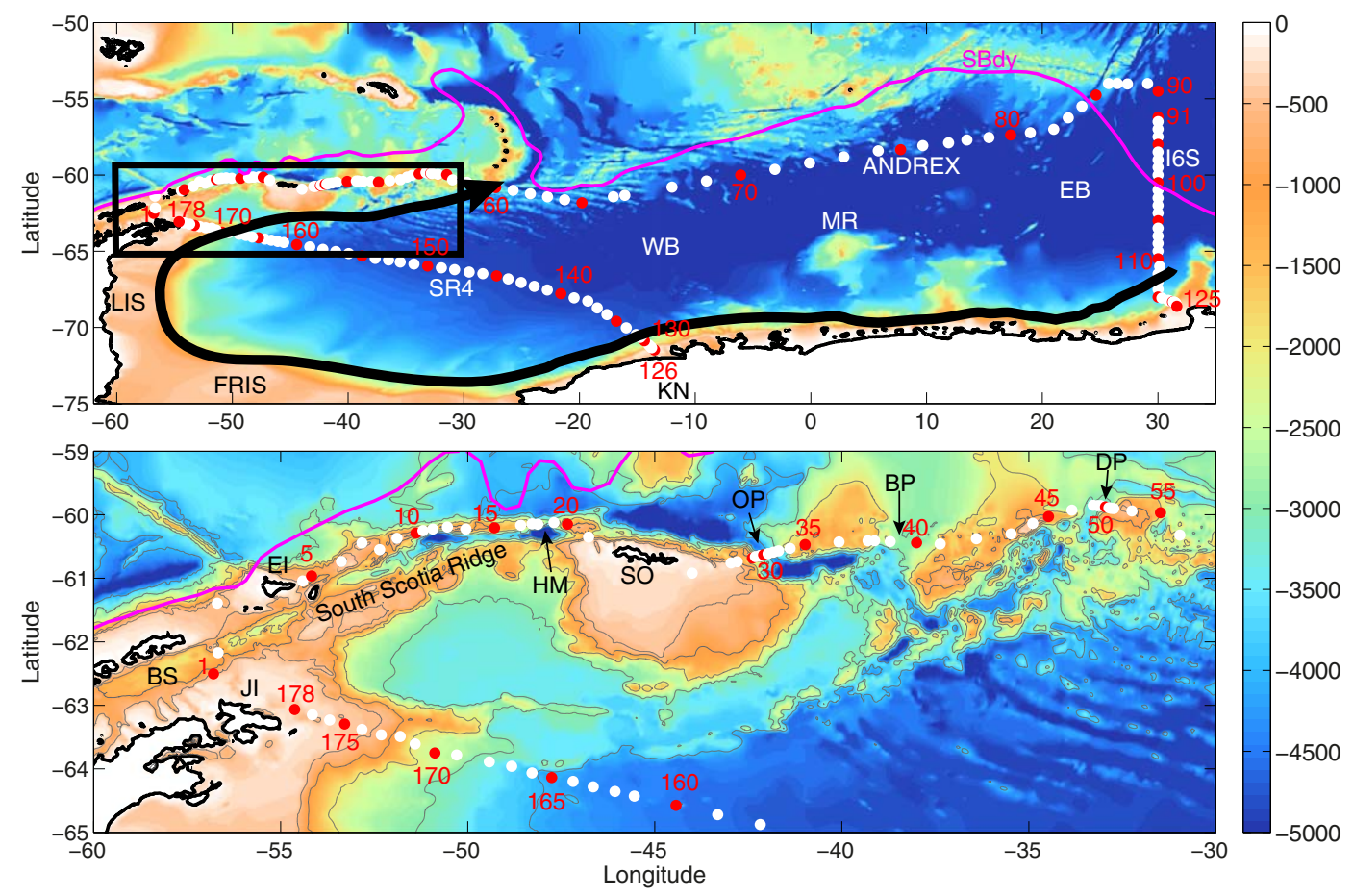

Figure 1. (top) Map and bathymetry (from GEBCO) of the Weddell Gyre region showing the three sections used in this study (ANDREX, 16S, SR4). For each section, the first and last stations as well as every fifth station are shown in red. The Southern Boundary of the ACC in magenta; the Weddell Gyre is indicated schematically by the black arrow. From left to right, LIS: Larsen Ice Shelves; FRIS: Filchner-Ronne Ice Shelves; KN: Kapp Norvegia; WB: Weddell Basin; MR: Maud Rise; and EB: Enderby Basin. (bottom) Detailed map of the South Scotia Ridge (black rectangle in top plot). From left to right, BS: Bransfield Strait; Jl: Joinville Island; El: Elephant Island; HM: Hesperides Mouth; SO: South Orkney Islands; OP: Orkney Passage; BP: Bruce Passage; and DP: Discovery Passage.

downstream, CDW interacts with dense, relatively saline waters cascading off the broad continental shelves of the southwestern and western Weddell Sea, resulting in the production of AABW [Gill, 1973; Foster and Carmack, 1976]. The regional variety of AABW is made up of two water masses: Weddell Sea Bottom Water (WSBW), produced primarily near the Filchner-Ronne ice shelves, is the coldest and densest AABW in the Weddell Gyre $\left(\theta<-0.7^{\circ} \mathrm{C}, \gamma^{n}>28.40 \mathrm{~kg} \mathrm{~m}^{-3}\right)$ [see Orsi et al., 1999]. The warmer and lighter Weddell Sea Deep Water (WSDW; $0>\theta>-0.7^{\circ} \mathrm{C}, 28.27<\gamma^{n}<28.40 \mathrm{~kg} \mathrm{~m}^{-3}$ ) may be formed directly by mixing between shelf waters and CDW, or indirectly by entrainment of CDW into WSBW as the shelf water plume cascades down the continental slope. A distinct variety of WSDW is formed near the Larsen ice shelves (LIS) in the western Weddell Sea that is lighter and fresher than deep water formed further south [Fahrbach et al., 1995; Gordon et al., 2001; Huhn et al., 2008; Gordon et al., 2010]. The reader may refer to Nicholls et al. [2009] for a detailed review of AABW in the Weddell Sea.

The newly formed AABW is conveyed northeastward by the Weddell Gyre and exported to the midlatitude Southern Ocean and beyond through openings in the topographic barriers bounding the gyre to the north, most conspicuously along the South Sandwich Trench near $25^{\circ} \mathrm{W}$ [Orsi et al., 1999]. In spite of the presumed high-ranking status of the Weddell Gyre in AABW formation, present estimates of AABW production in the gyre are unsatisfactorily wide-ranging (Table 1). These differences represent a combination of inconsistencies between different estimation techniques, AABW definitions or regional flow regimes; and temporal variability [Naveira Garabato et al., 2002a]. This large uncertainty in the quantification of water mass transformation and ventilation in the Weddell Gyre has historically posed a significant obstacle to determining its standing in the closure of the GOC.

There are now several pieces of evidence that challenge this traditional view of the Weddell Gyre. Most fundamentally, the long-held notion of the gyre as a largely hermetic bowl with a few, well-defined inflow and outflow pathways is inconsistent with observations. Klatt et al. [2005] point out the existence of a substantial inflow of CDW into the gyre along its northern rim, while Gordon et al. [2001] and Naveira Garabato 


\section{QAGU Journal of Geophysical Research: Oceans}

Table 1. Summary of the Historical Estimates of Antarctic Bottom Water, Weddell Sea Bottom Water, and Weddell Sea Deep Water Production in the Weddell Sea

\begin{tabular}{|c|c|c|c|c|}
\hline \multirow[b]{2}{*}{ Source } & \multirow[b]{2}{*}{ Method } & \multicolumn{3}{|c|}{ Production Rate (Sv) } \\
\hline & & WSDW & WSBW & AABW \\
\hline This study & Inverse model & $2 \pm 2$ & $4 \pm 2$ & $6 \pm 2$ \\
\hline Kerr et al. [2012] & Numerical model & & & $10.6 \pm 3.1$ \\
\hline Wang et al. [2009] & Numerical model & & 2.2 & \\
\hline Huhn et al. [2008] & CFC and noble gas inventory & & $5.0 \pm 1.2$ & \\
\hline Lumpkin and Speer [2007] & Inverse Model & & & $5.6 \pm 3.0$ \\
\hline Klatt et al. [2005] & Geostrophic transport & & 3 & \\
\hline Foldvik et al. [2004] & DBC transport & & $4.3 \pm 1.4$ & \\
\hline Naveira Garabato et al. [2002a] & Inverse Model & $5.8 \pm 3.0$ & $3.9 \pm 0.8$ & $9.7 \pm 3.7$ \\
\hline Orsi et al. [2002] & CFC inventory & 4.9 & & \\
\hline Schodlok et al. [2002] & Numerical model & $6.4 \pm 0.6$ & & \\
\hline Sloyan and Rintoul [2001] & Inverse Model & & & $11 \pm 1$ \\
\hline Harms et al. [2001] & Freshwater budget & & 2.6 & \\
\hline Fahrbach et al. [2001] & DBC transport & & $1.3 \pm 0.4$ & \\
\hline Meredith et al. [2001] & CFC inventory & & & $3.7 \pm 1.6$ \\
\hline Orsi et al. [1999] & CFC inventory & & & 4.9 \\
\hline Gordon [1998] & DBC transport & & $5-4$ & \\
\hline Mensch et al. [1996] & CFC inventory & & 11 & \\
\hline Fahrbach et al. [1995] & DBC transport & & 1.4 & \\
\hline Fahrbach et al. [1994] & DBC transport & 2.6 & 1.2 & \\
\hline Fahrbach et al. [1991] & Geostrophic transport & & $3-4$ & \\
\hline Foster and Carmack [1976] & $\mathrm{DBC}$ transport & & 3.6 & \\
\hline Carmack and Foster [1975] & DBC transport & & $2-5$ & \\
\hline Gill [1973] & Shelf Water budget & & $6-9$ & \\
\hline
\end{tabular}

et al. [2002a] suggest that AABW may be exported from the gyre across a wider zonal swath than previously thought, including the major topographic barrier of the South Scotia Ridge. A most unexpected finding in this context relates to the observation of a prominent flow of AABW from the Indian Ocean sector entering the southern Weddell Gyre across its eastern rim [Meredith et al., 2000; Hoppema et al., 2001; Couldrey et al., 2013], which has led to the (as yet untested) proposition that the role of the gyre in AABW formation has been historically overstated [Jacobs, 2004].

Here we seek to characterize the contribution of the Weddell Gyre to the closure of the lower limb of the GOC by diagnosing the gyre's three-dimensional circulation and water mass transformations with a box inverse model. The model is articulated around four hydrographic transects (Figure 1) spanning the gyre's inner reaches and outer rim, conducted over a 5 year period centered on the 2007-2008 International Polar Year (Table 2). The data sources and model design are described in sections 2 and 3, respectively. Results are presented in sections 4 and 5, where the former addresses the gyre's lateral circulation and thermodynamical budgets, and the latter describes the vertical circulation. Section 6 discusses the implications of our results for the present paradigm of the Weddell Gyre circulation. Our main findings are synthesized in section 7 .

\section{Data}

\subsection{Hydrographic Data}

Four hydrographic transects spanning 5 years (2005-2010) were analyzed in this study (Table 2). The configuration of the inverse model box, which incorporates two complete coast-to-coast sections, allows us to differentiate between the water mass transformations and overturning circulation occurring in association

\begin{tabular}{|c|c|c|c|c|c|c|}
\hline Year & Month & Vessel & Cruise Number & Section Name & Box Station Number & Reference \\
\hline 2005 & $01-02$ & PFS Polarstern & ANT XXII/3 & SR4 & $126-178$ & Fahrbach [2005] \\
\hline 2008 & $02-03$ & RV Roger Revelle & 33RR20080204 & $16 \mathrm{~S}$ & $91-125$ & Speer and Dittmar [2008] \\
\hline 2009 & 01 & RRS James Cook & JC30 & ANDREX & $67-90$ & Bacon and Jullion [2011] \\
\hline 2010 & 03-04 & RRS James Clark Ross & JR239 & ANDREX & $1-66$ & Meredith [2010] \\
\hline
\end{tabular}

${ }^{\mathrm{a}}$ The station numbers for each section in the box is indicated. 
with shelf-slope processes in the vicinity of the continental shelves and ice shelves of the southwestern Weddell Sea, and the contributions to transformations and overturning by gyre interior processes. CTD profiles of temperature and salinity were measured during the cruises, as well as velocity with vessel-mounted and lowered acoustic Doppler current profilers. All four hydrographic cruise data sets were subjected to secondary quality control testing by performing crossover analyses with CARINA [Key et al., 2010] and GLODAP [Key et al., 2004] regional data products [following Hoppema et al., 2009] to analyze for systematic biases inherent in individual cruise measurements. In this work, crossover analyses were performed for salinity only; as occurred during GLODAP, CARINA, and PACIFICA [Key et al., 2004, 2010; Tanhua et al., 2010] temperature was not analyzed as it is considered by far the most accurately measured parameter and it is assumed that its random and systematic errors are negligible. All four salinity data sets used in the Weddell region inversion were found to be of high quality, with derived data offsets being below the adjustment threshold of 0.005 .

The $16 \mathrm{~S}$ section, a quasi-meridional line along $30^{\circ} \mathrm{E}$ between South Africa and Antarctica, was occupied under the auspices of CLIVAR in February-March 2008 by the RV Roger Revelle (cruise 33RR20080204). 106 CTD stations with a characteristic spacing of $30 \mathrm{~km}$ were collected during the cruise [Speer and Dittmar, 2008], and 54 of them are used in this study.

The ANDREX section, extending quasi-zonally from the tip of the Antarctic Peninsula to $30^{\circ} \mathrm{E}, 55^{\circ} \mathrm{S}$ (station 90 in Figure 1), was originally scheduled to be occupied in one single cruise in January 2009 (Table 2). However, after 27 stations (corresponding to station 73 in Figure 1 near $19^{\circ} \mathrm{W}, 61^{\circ} \mathrm{S}$ ), the JC30 cruise [Bacon and Jullion, 2011] was aborted due to a medical evacuation. A second cruise, JR239 [Meredith, 2010], was conducted $\sim 1$ year later (March-April 2010) to complete the section. Sixty-eight stations were occupied during this cruise, including a repeat of the ALBATROSS transect (March-April 1999) over the South Scotia Ridge [Naveira Garabato et al., 2002b]. West of the South Orkney Islands, heavy sea ice conditions precluded an exact repeat of the ALBATROSS line, and stations were placed on a more northerly sector of the South Scotia Ridge. The JC30, JR239, and I6S transects were merged into one section extending from the tip of the Antarctic Peninsula to the Antarctic coast at $30^{\circ} \mathrm{E}$. We refer to this merged section as ANDREX/I6S.

The SR4 section, between Kapp Norvegia and Joinville Island (Figure 1), was due to be occupied in full in January-February 2008 by cruise ANTXXIV of the PFS Polarstern. However, the slope current near Kapp Norvegia could not be sampled during this transect due to heavy sea ice conditions and a tragic medical evacuation. We therefore chose to use the previous occupation of the section (cruise ANTXXII in JanuaryFebruary 2005) in our analysis [Fahrbach, 2005].

\subsection{Sea Ice}

Daily means of sea ice concentration were derived from the Special Sensor Microwave/Imager (SSM/I) Passive Microwave sensor using the NASA Team algorithm for the period 2005-2010 [Cavalieri et al., 1996]. The daily ice motion data were derived from the same sensor and period using the Fowler algorithm. These data were provided as a personal communication by Chuck Fowler and Mark Tschudi (2003, Sea ice concentrations from nimbus-7 SMMR and DMSP SSM/I-SSMIS passive microwave data, technical report, Natl. Snow and Ice Data Cent., Boulder, Colo.).

Sea ice thickness data are extremely scarce, due to the difficulty in accessing ice-covered areas, particularly during winter. We estimated a climatological sea ice thickness from the ASPeCt data set (http://aspect.antarctica.gov.au/), which archives data from 83 voyages and two helicopter flights for the period 1980-2005 [Worby et al., 2008]. To calculate sea ice volume fluxes, the 6 year mean of the daily products of sea ice concentration and velocity across each section are multiplied by the climatological sea ice thickness distribution and the array of distances between data points.

\subsection{Southern Ocean State Estimate (SOSE)}

SOSE is a high-resolution ( $\left.1 / 6^{\circ} \mathrm{grid}\right)$ numerical model of the Southern Ocean with data assimilation covering the 2005-2010 period [Mazloff et al., 2010]. Comparison with our observations showed the model to suffer from a cold $\left(0.01-0.02^{\circ} \mathrm{C}\right)$ and fresh $(0.01-0.02)$ bias, resulting in an abyssal stratification that is stronger than observed in the center of the gyre across the SR4 section. Further north, the performance of SOSE improves, likely as a result of an increase in the abundance of observations used in constraining the model. Despite these discrepancies, the temporal variability of the modeled flow reflects our understanding of the 
regional circulation, with elevated variability over the continental slopes around the Antarctic Slope Front (ASF), within the ACC and over the South Scotia Ridge, and reduced variability in the interior of the Weddell Gyre. We use SOSE to assess the uncertainties in the reference velocities across the rim of the model box, and to estimate the contribution of the time-varying (eddy) circulation to the volume, potential temperature, and salinity budgets of the model domain.

\section{A Box Inverse Model of the Weddell Gyre}

We combine the four transects described in the preceding section in a box inverse model of the Weddell Gyre (Figure 1). The box is constructed as follows, from the Antarctic Peninsula going clockwise: stations 1-66 correspond to the JR239 cruise, stations 67-90 to the JC30 cruise, stations 91-125 to the I6S cruise, and stations 126-178 to the SR4 cruise (Table 2). In the following, we will refer to the region encompassed by the outer sections as simply the main box, and the smaller region enclosed by SR4 and the continent as the Southwest (SW) box. Box inverse modeling [Wunsch, 1996] provides an effective technique to estimate the large-scale ocean circulation by combining observations in a theoretical framework in which conservation of mass, heat, salt (or, equivalently, volume, potential temperature, and salinity) and other tracers may be enforced.

\subsection{Hydrographic Setting}

Figure 2 shows the vertical distribution of potential temperature and salinity along the rim of the main box. In the northeastern corner, the ACC is visible in potential temperature and salinity maxima near stations $85-$ 97 and extends nearly all the way to the continental slope, as evidenced by the southward-shoaling isopycnals along the I6S section. Near the continental slope, the ASF (stations 111-125) is marked by a southward deepening of isopycnals and a thick layer of cold and fresh WW.

Along the SR4 transect, a section-wide doming of isopycnals denotes the cyclonic Weddell Gyre. Near Kapp Norvegia, the ASF (stations 128-132) conveys relatively warm and saline CDW and a thick layer of WW toward the Filchner-Ronne ice shelves (Figure 2). Near Joinville Island (near station 172), the presence of newly formed, dense WSBW against the continental slope leads to the characteristic "V" shape of the ASF in that sector. The thick layer of cold WW observed near Kapp Norvegia is eroded in the SW box and flows back into the box considerably thinner near Joinville Island. Thompson and Heywood [2008] provide a more detailed description of the frontal structure of the SR4 section near Joinville Island, identifying several frontal jets which, for the sake of simplicity, we collectively refer to as the ASF in this study.

Over the South Scotia Ridge, several deep passages provide a direct route for deep waters of Weddell Sea origin to enter the Scotia Sea (see Naveira Garabato et al. [2002b] for a detailed description of the water masses and their pathways over the ridge). East of the ridge, the Weddell Front (between stations 60 and 61) separates relatively warm and saline CDW to the north from colder and fresher CDW in the inner Weddell Gyre, and is associated with a pronounced northward flow.

\subsection{Model Setup}

The ANDREX-16S and SR4 sections are divided vertically into 10 layers separated by neutral density interfaces [Jackett and McDougall, 1997], as indicated in Table 3. The interfaces are selected to correspond with the boundaries of the major water masses in the region. Within the main box bounded by the sections, we enforce conservation of mass, heat, and salt, represented in the model as volume, potential temperature anomaly, and salinity anomaly, in each layer and full depth. Full details of the model implementation (including initialization, solution procedure, choice of weights, and calculation of posterior uncertainties) are given in the supporting information and are summarized here. We write the full-depth conservation statement for any given tracer as

$$
\sum_{\jmath=1}^{m}\left[\sum_{l=1}^{n}\left[\delta_{l} L_{l} D_{l \jmath}\left(V_{l \jmath}+b_{l}\right) \rho_{l \jmath} C_{l \jmath}\right]+v_{\jmath}(C)-\left[A \overline{\rho C \omega_{c}^{*}}\right]_{\gamma_{\jmath}}^{\gamma_{\jmath}+1}+F_{\jmath}^{A-S}(C)+F_{\jmath}^{S I}(C)\right]=0
$$

where $n$ is the number of station pairs; $m$ is the number of layers; $\delta_{i}$ adopts the value +1 or -1 depending on whether flow is directed into or out of the box; $L_{l}$ and $D_{l \jmath}$ are the distance between successive stations 

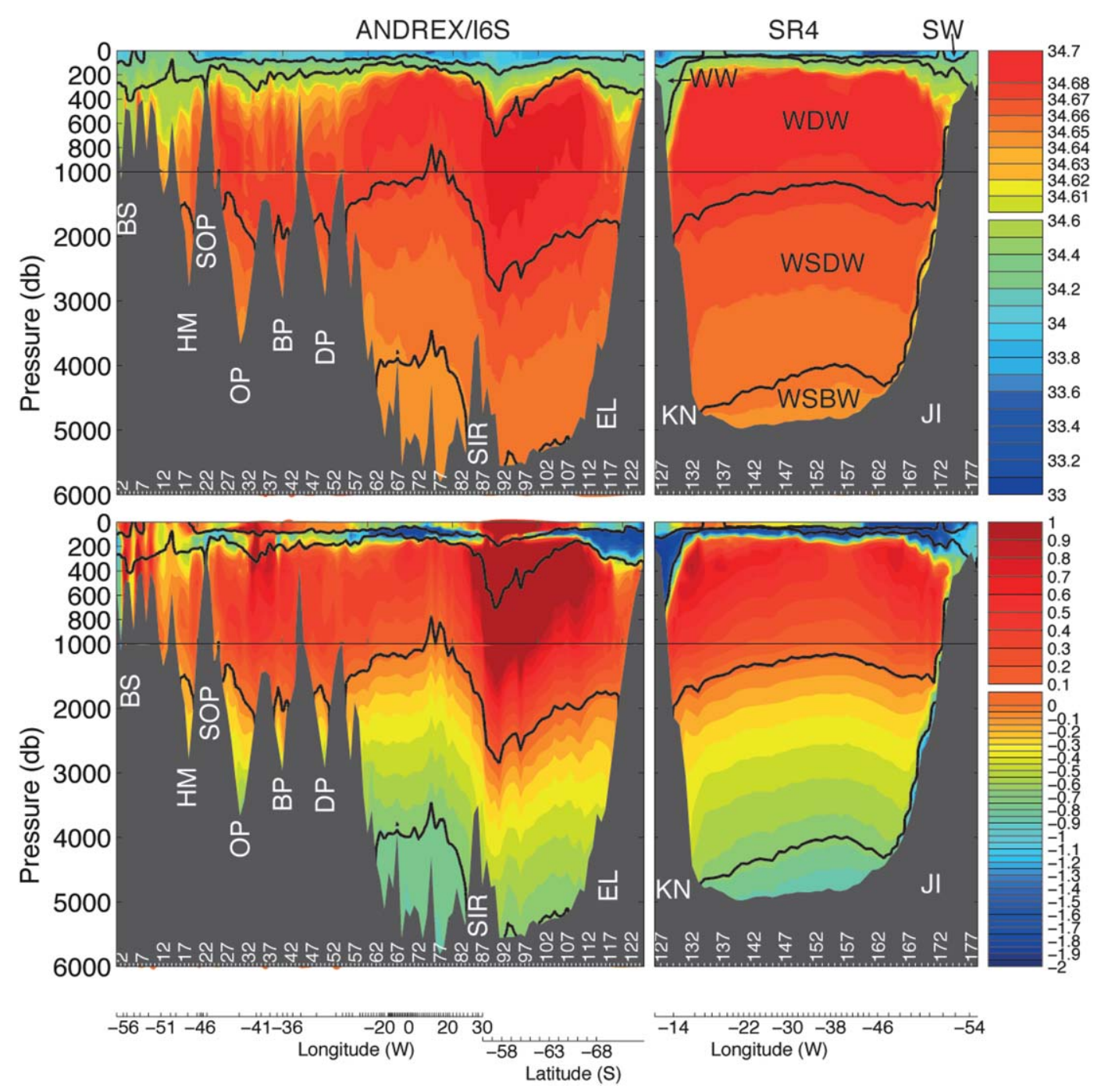

Figure 2. (top) Salinity and (bottom) potential temperature along the rim of the model box going clockwise from the Antarctic Peninsula (station 1) along the ANDREX/I6S section and SR4 section back to Joinville Island (station 175). Water mass neutral density boundaries (Table 3) are shown as black contours. Water masses and stations are labeled in black and white, respectively. The main bathymetric features are labeled in white. From left to right, BS: Bransfield Strait, HM: Hesperides Mouth, SOP: South Orkney Plateau, OP: Orkney Passage, BP: Bruce Passage, DP: Discovery Passage, SIR: South Indian Ridge, and EL: Enderby Land. Water masses as defined in Table 3: WW: Winter Water; CDW: Circumpolar Deep Water; WSDW: Weddell Sea Deep Water; and WSBW: Weddell Sea Bottom Water.

and the layer thickness at each station pair, respectively; $\mathrm{V}_{l j}$ is the baroclinic velocity at the station pair $i$ and layer $j ; b_{l}$ is the barotropic velocity at station pair $i ; \rho_{l j}$ is in situ density; $A$ is the area of the layer interface within the box; $\omega_{C}^{*}$ is the diapycnal velocity for tracer $C$ [Mclntosh and Rintoul, 1997; Sloyan and Rintoul, 2000]; $F_{J}^{A-S}(C)$ and $F_{j}^{S l}(C)$ are the fluxes of tracer $C$ associated with air-sea interactions and sea ice, respectively; $v_{\jmath}(C)=\rho_{\jmath}\left[{\overline{v^{\prime} C^{\prime}}}^{t} \bar{h}^{t}+{\overline{v^{\prime} h^{\prime}}}^{t} \bar{C}^{t}\right]$, is the eddy-induced flux of tracer $C$ for the layer $\jmath$, which consists of advective (the first) and diffusive (the second) components; $v^{\prime}$ and $h^{\prime}$ are the deviation from the timeaveraged mean velocity and isopycnal layer thickness calculated from SOSE; $\overline{(\cdot)}{ }^{\gamma}$ and $\overline{(\cdot)}^{t}$ denote the areamean operator over a layer interface and the time-mean operator, respectively (see supporting information section 2a). We note that the model incorporates two sets of terms (sea ice-mediated and eddy-induced transports) that are not normally represented in box inverse models, but that are important in the context of the Weddell gyre (see supporting information section 2a). The model is underdetermined, having a total of 238 unknowns (175 barotropic velocities; 27 diapycnal velocities; 30 eddy flux terms; 2 sea ice transport terms, across ANDREX/I6S and SR4; 2 air-sea heat flux terms, one in the box and one south of SR4; and 2 airsea freshwater terms, one in the box and one south of SR4) and only 40 equations (conservation of volume, 
Table 3. Model Layer Definitions and Characteristics: A Priori Errors in the Volume Conservation for Model Layers Following the Recommendations of Ganachaud [2003] ${ }^{\mathrm{a}}$

\begin{tabular}{|c|c|c|c|c|c|}
\hline$\gamma_{n}$ Limits $\left(\mathrm{kg} \mathrm{m}^{-3}\right)$ & Layer Number & Error (Sv) & $\bar{\theta} \pm s t d(\theta)\left({ }^{\circ} \mathrm{C}\right)$ & $\bar{S} \pm s t d(S)$ & Water Mass \\
\hline Sea surface-27.70 & 1 & 4 & $-0.40 \pm 0.72$ & $33.947 \pm 0.167$ & SW \\
\hline $27.70-28.00$ & 2 & 4 & $-0.69 \pm 0.89$ & $34.385 \pm 0.068$ & wW \\
\hline $28.00-28.10$ & 3 & 3 & $-0.18 \pm 0.89$ & $34.568 \pm 0.069$ & \\
\hline $28.10-28.20$ & 4 & 3 & $0.38 \pm 0.31$ & $34.666 \pm 0.030$ & CDW \\
\hline $28.20-28.27$ & 5 & 2 & $0.17 \pm 0.21$ & $34.673 \pm 0.020$ & \\
\hline $28.27-28.31$ & 6 & 2 & $-0.09 \pm 0.07$ & $34.668 \pm 0.006$ & \\
\hline $28.31-28.35$ & 7 & 2 & $-0.33 \pm 0.08$ & $34.661 \pm 0.006$ & \\
\hline $28.35-28.37$ & 8 & 2 & $-0.48 \pm 0.08$ & $34.656 \pm 0.004$ & WSDW \\
\hline $28.37-28.40$ & 9 & 2 & $-0.59 \pm 0.08$ & $34.653 \pm 0.004$ & \\
\hline 28.40-sea floor & 10 & 1 & $-0.73 \pm 0.06$ & $34.648 \pm 0.005$ & WSBW \\
\hline Full depth & 11 & 1 & $-0.14 \pm 0.33$ & $34.603 \pm 0.090$ & \\
\hline
\end{tabular}

${ }^{a}$ The mean and standard deviation of the $\theta$ and $\mathrm{S}$ of each layer are quoted, and water mass equivalences indicated (SW: Surface Water; WW: Winter Water; CDW: Circumpolar Deep Water; WSDW: Weddell Sea Deep Water; WSBW: Weddell Sea Bottom Water).

potential temperature, and salinity in 10 isopycnal layers and full depth). Further to conservation within the main box, we include additional constraints on the volume and salinity anomaly transports across the two coast-to-coast sections (Figure 1) and within the ACC (Table 4).

As the underdetermined nature of the system allows an infinite number of solutions, we specify an a priori solution based on observations in order to guide the model. The initial geostrophic transport is calculated by fitting the geostrophic shear to lowered-ADCP (when available) or shipboard-ADCP data (see supporting information, section $2 b$, for the initialization of the other variables). The set of equations (1) may be reduced to

$$
E \mathbf{x}+\mathbf{n}=\mathbf{y},
$$

where $E$ is the matrix of conservation statements, $\mathbf{x}=\left[b_{l}, \omega_{C}^{*}, F_{j}^{A-S}(C), F_{j}^{S I}(C), v_{\jmath}(C)\right]$ groups the unknowns, $\mathbf{y}$ contains the observation-based prior imbalances in the conservation equations, and $\mathbf{n}$ is the noise term, which amalgamates the prior uncertainties in each of the unknowns and conservation statements. Row and column weighting are applied to the model (equation (2)) in order to weight constraints and unknowns, respectively. The weighted system (2) is solved using singular value decomposition [Wunsch, 1996].

\subsection{The Standard Solution}

In solving (2), a solution rank of 28 (out of 40 model equations) is selected. This choice corresponds to the lowest rank that provides a dynamically acceptable solution, for which posterior equation residuals are indistinguishable from zero within one posterior standard deviation (Figure 3) and perturbations to the initial estimates of the unknowns are within one a priori standard deviation (Figure 4a). Flux (heat and freshwater) calculations require a closed mass budget, so (small) residuals to the standard solution are eliminated by a second model run with solely two constraints: full-depth volume and salinity conservation applied to horizontal reference velocities only (Layer 11 in Figure 3). The root mean square adjustment to the initial barotropic velocities is $0.045 \mathrm{~m} \mathrm{~s}^{-1}$ (Figure 4b), with the largest perturbations being produced on the Antarctic continental shelf at the $16 \mathrm{~S}$ section $\left(0.34 \mathrm{~m} \mathrm{~s}^{-1}\right)$. In contrast, barotropic velocity corrections in the Weddell-Enderby basin (station pairs 65-80) are small $\left(<0.01 \mathrm{~cm} \mathrm{~s}^{-1}\right)$.

Adjustments to other variables are generally modest. Thus, the diapycnal velocities in the standard solution have an RMS value $4.9 \times 10^{-7} \mathrm{~m} \mathrm{~s}^{-1}$, a magnitude characteristic of open ocean environments away from boundaries. The initial sea ice volume transports across the SR4 and ANDREX/I6S sections are reduced by $41 \%$ and $7 \%$, respectively (Table 5 ). The net addition of volume due to precipitation and glacial runoff is increased by $4 \%$ south of SR4 and decreased by $42 \%$ within the main box, respectively

(Table 5). Finally, the root-mean-

Table 4. Extra Conservation Constraints Applied to the Model ANDREX/16S (1-123) SR4 (124-175)

\begin{tabular}{lccc} 
& ANDREX/16S (1-123) & SR4 (124-175) & ACC (82-111) \\
\hline Full depth volume trans. & $0 \pm 1 \mathrm{~Sv}$ & $0 \pm 1 \mathrm{~Sv}$ & $0 \pm 5 \mathrm{~Sv}$ \\
Full depth S anom trans. & $0 \pm 1 \mathrm{~Sv}$ & $0 \pm 1 \mathrm{~Sv}$ & $0 \pm 5 \mathrm{~Sv}$
\end{tabular}
square (RMS) corrections applied to the eddy fluxes of volume, potential temperature, and salinity are $20 \%$, 50\%, and $10 \%$, respectively. 

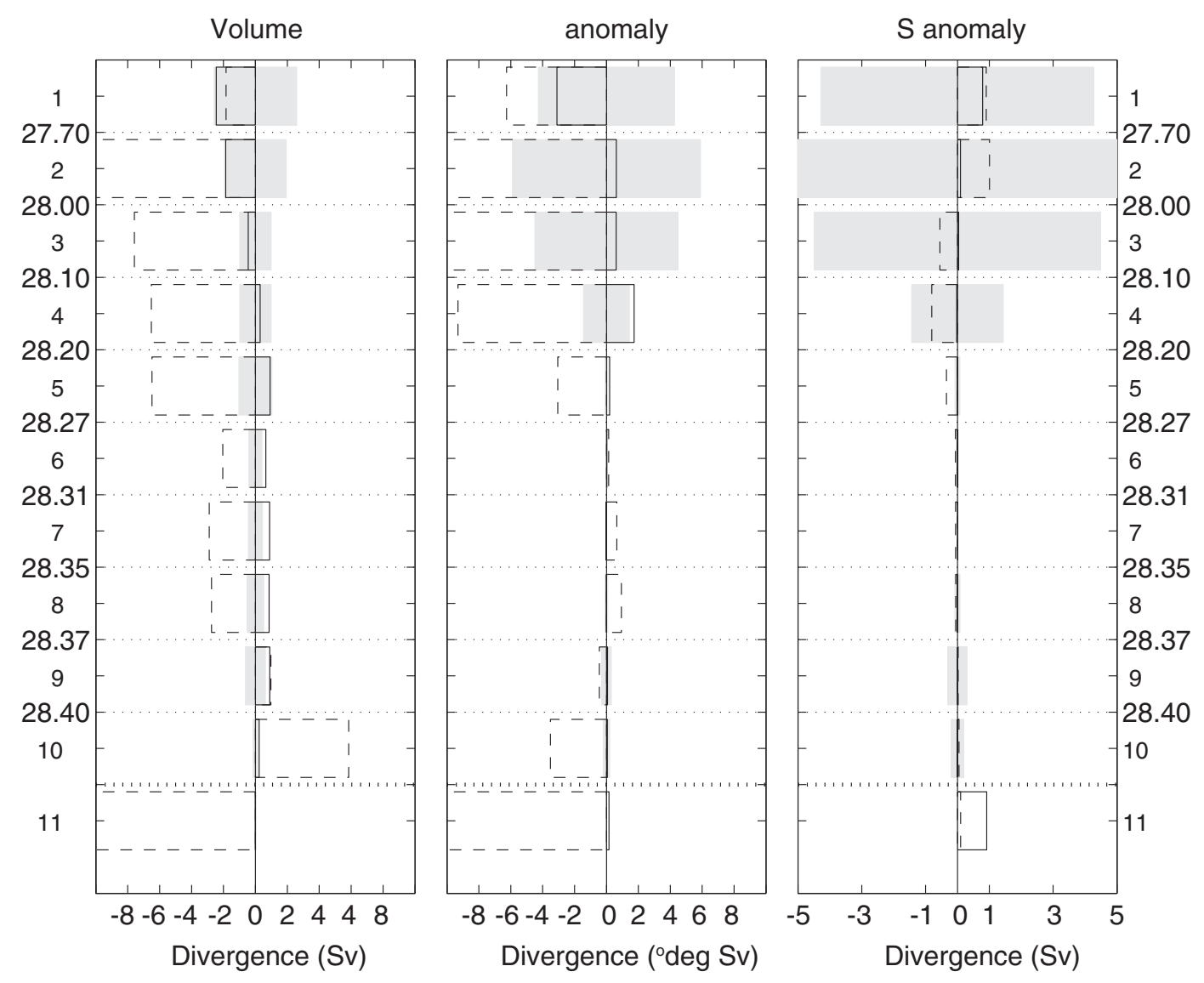

Figure 3. Transport divergence for the box: (a) volume, (b) potential temperature anomaly, and (c) salinity anomaly (right) before (black dashed lines) and after (black lines) inversion. The neutral density limits of the layers are shown as black dotted lines. Gray bars are posterior uncertainties calculated using the Gauss-Markov formalism. Positive is into the box, negative is out of the box.

\section{Horizontal Circulation, Heat, and Freshwater Budgets of the Weddell Gyre}

\subsection{Horizontal Circulation}

The circulation of the southwestern Weddell Sea is associated with northward volume exports of $12 \pm 3$ $\mathrm{mSv}$ of liquid water and of $10 \pm 1 \mathrm{mSv}\left(315 \pm 32 \mathrm{~km}^{3} \mathrm{yr}^{-1}\right)$ of sea ice across the SR4 section, balanced by a net meteoric (precipitation plus glacial runoff minus evaporation) freshwater input to the ocean in the SW box of $22 \pm 3 \mathrm{mSv}$, equivalent to a mean net precipitation rate of $389 \pm 53 \mathrm{~mm} \mathrm{yr}^{-1}$ over the ocean (Table 5). This volume transport is enhanced by a further meteoric input of $28 \pm 4 \mathrm{mSv}$ (equivalent to a mean net precipitation rate of $\left.230 \pm 25 \mathrm{~mm} \mathrm{yr}^{-1}\right)$ within the main box, and $4 \pm 1 \mathrm{mSv}\left(126 \pm 32 \mathrm{~km}^{3} \mathrm{yr}^{-1}\right)$ of sea ice are produced in that region. This leads to a net northward volume export out of the Weddell Gyre of $51 \pm 190$ $\mathrm{mSv}$, of which $36 \pm 190 \mathrm{mSv}$ occur in liquid form and $15 \pm 2 \mathrm{mSv}\left(473 \pm 63 \mathrm{~km}^{3} \mathrm{yr}^{-1}\right)$ as sea ice.

The geostrophic velocity field and barotropic velocities (Figures $4 \mathrm{~b}$ and $4 \mathrm{c}$ ) reproduce the main known features of the large-scale circulation of the Weddell Gyre. An inner gyre transport of $42 \pm 8 \mathrm{~Sv}\left(1 \mathrm{~Sv}=10^{6} \mathrm{~m}^{3}\right.$ $\mathrm{s}^{-1}$ ) is diagnosed across the SR4 section, and an outer gyre transport of $54 \pm 15 \mathrm{~Sv}$ is found across the ANDREX/I6S section (station pairs 1-72, Figure 4d). In this section (stations 82-111), the SACCF and Southern Boundary of the ACC convey $68 \pm 18$ Sv into and out of the northeastern corner of the model domain. While this is a large transport, comparable to that of the Weddell Gyre, it leads to a small net transport $(2 \pm 5 \mathrm{~Sv}$ ) into the main box, as dictated by the additional ACC transport constraint (Table 4).

A substantial fraction (85\%) of the Weddell Gyre transport is focussed around the ASF, and in the area where the ASF disintegrates over the South Scotia Ridge. At the gyre's eastern edge, in the $16 \mathrm{~S}$ section, the ASF transports $24 \pm 4$ Sv westward into the gyre, primarily in the most voluminous water masses (CDW and WSDW, see Figure 4e; see also Table 6). Further downstream, the ASF transport entering the SW box has 

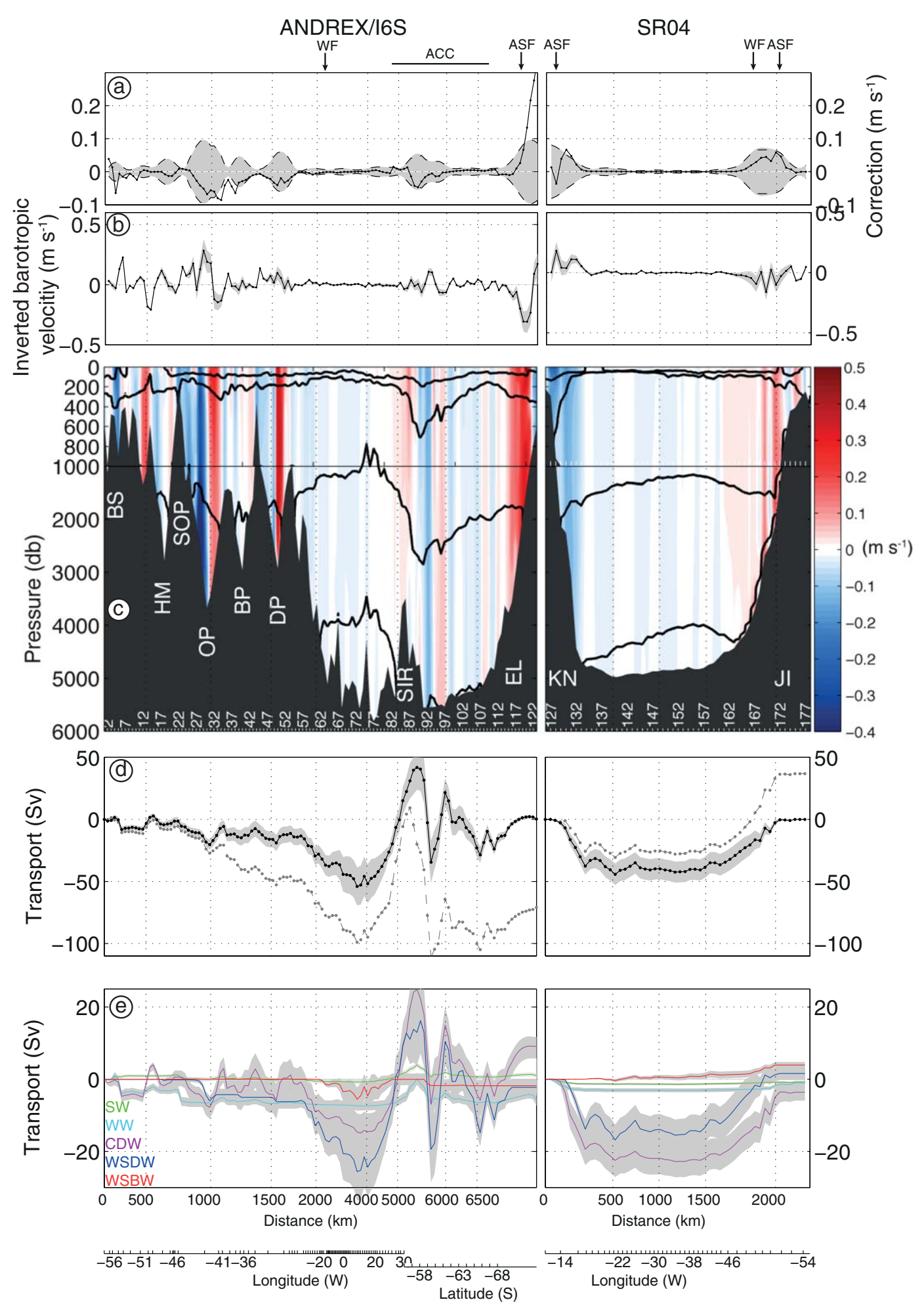

Figure 4. (a) Corrections applied by the inverse model to the barotropic velocities; the shaded envelope is the prior uncertainty, and the dashed line the posterior uncertainty. (b) Inverted barotropic velocities (initial + correction); the gray envelope indicates the prior uncertainty. (c) Geostrophic velocity, with positive (negative) values indicating flow into (out of) the model box. Black contours represent the water mass boundaries. (d) Accumulated (clockwise from the Antarctic Peninsula to the Enderby Land for ANDREX/I6S and from Kapp Norvegia until Joinville Island for SR4) full-depth volume transport (in Sv), with the same sign convention as in Figure 4c: prior (dashed black line) and posterior (black line). (e) Accumulated volume transport (in Sv) of individual water masses, as labeled. 


\section{QAGU Journal of Geophysical Research: Oceans}

Table 5. A Priori and A Posteriori Values for the Sea Ice, Air-Sea-lce Heat, and Meteoric Water Fluxes

\begin{tabular}{lcccccc} 
& & & \multicolumn{3}{c}{ ANDREX/I6S } \\
\cline { 5 - 7 } & Sea-Ice $(\mathrm{mSv})$ & SR4 Heat TW & Met. Water $(\mathrm{mSv})$ & Sea-Ice $(\mathrm{mSv})$ & Heat TW & Met. Water $(\mathrm{mSv})$ \\
\hline A priori & $18 \pm 9$ & 0 & $21 \pm 11$ & $16 \pm 8$ & 0 & $49 \pm 25$ \\
A posteriori & $10 \pm 1$ & $26 \pm 18$ & $22 \pm 3$ & $4 \pm 1$ & $10 \pm 1$ & $28 \pm 4$ \\
\hline
\end{tabular}

increased to $38 \pm 8 \mathrm{~Sv}$, as a result of recirculation in the gyre. A similar ASF transport ( $37 \pm 9 \mathrm{~Sv}$ ) is found at the northern end of the SR4 transect, off Joinville Island. The breakdown of the ASF over the South Scotia Ridge is evident in the ANDREX section, where the frontal signature is associated with a weak transport of $8 \pm 2 \mathrm{~Sv}$ at station pair 5, just east of Elephant Island (Figure 4d). This is in line with previous findings by Heywood et al. [2004] and Thompson et al. [2009] on the basis of hydrographic and surface drifter measurements.

The remainder of the flow associated with the ASF entering the northwestern Weddell Sea contributes both to net northward transports of $15 \pm 7$ Sv over the South Scotia Ridge (on the western flanks of the Hesperides, Orkney, Bruce, and Discovery passages) and of $25 \pm 6 \mathrm{~Sv}$ further east in association with the Weddell Front (Figure $4 \mathrm{c}$ and Table 7). The presence of an interior recirculation of some $20 \mathrm{~Sv}$ in the center of the Weddell-Enderby Basin (between $10^{\circ} \mathrm{W}$ and $20^{\circ} \mathrm{E}$ ) is indicated by the reversal of the transport between station pairs 75 and 82. The existence of a recirculation cell north of Maud Rise had been suggested by Beckmann et al. [1999] and Fahrbach et al. [2011], and explains the increase in the ASF transport between the I6S and SR4 sections. The eddy contribution to the volume budget is small $(-0.4 \pm 0.2 \mathrm{~Sv})$ compared with the mean transport suggesting a relatively modest eddy advection (Figure $5 \mathrm{a}$ ).

Due to the largely equivalent barotropic nature of the flow, the circulation of deep and bottom waters in the Weddell Gyre reflects strongly the full-depth transport. CDW and WSDW circulate cyclonically around the gyre. A total of $14 \pm 2$ Sv of CDW and $9 \pm 2$ Sv of WSDW flow westward into the gyre across the I6S section, with $19 \pm 4$ Sv and $14 \pm 3$ Sv, respectively, entering the SW box across the southern end of the SR4 transect (Table 6). As the gyre circulates back across the northern edge of that section, the transport of WSBW has increased from 0 to $4 \pm 2 \mathrm{~Sv}$, with little modification in the transport of CDW and WSDW. Approximately $75 \%$ ( $3 \pm 1 \mathrm{~Sv}$ ) of the WSBW outflow from the SW box occurs in a thin bottom layer over the continental slope of the northern Antarctic Peninsula (Figure 2 and Table 6) and the remaining 25\% in the abyssal Weddell Sea. The bulk of the WSDW export from the gyre toward the midlatitude Southern Ocean (a total of $17 \pm 4 \mathrm{~Sv}$ ) occurs between station pairs 1 and 69 , with $6 \pm 2 \mathrm{~Sv}$ of newly ventilated WSDW flowing over the South Scotia Ridge and $11 \pm 4$ Sv being exported to the east of the Scotia Sea. The WSBW is generally too dense to overflow the ridge system bounding the Weddell Gyre to the north, and largely recirculates cyclonically between station pairs 63 and 82. Only $2 \pm 1$ Sv of WSBW are found to flow northward out of the model domain, in station pairs 92-93, toward the Indian Ocean midlatitudes.

\subsection{Heat Budget}

The net flux of heat entering the Weddell Gyre across the ANDREX/I6S section is $36 \pm 13$ TW (Figure 6). The bulk of this value is contributed by the ocean circulation, which accounts for $31 \pm 13$ TW. Of this, $5 \pm 1$ TW is by eddy-induced transports (Figure $5 b$ ), indicating that transient eddies play a significant role in the

Table 6. Water Mass and Full-Depth Volume Transports (in Sv) Diagnosed by the Inverse Model Within the Antarctic Slope Front Across the 165 Section (Left), Near Kapp Norvegia Across the SR4 Transect (Middle), and Near Joinville Island (Right) Diagnosed by the Inverse Model $^{\mathrm{a}}$

\begin{tabular}{lccr} 
Water Mass & I6S (112-123) & SR4 Kapp Norvegia (124-131) & SR4 Joinville Island (159-175) \\
\hline SW & $0 \pm 0$ & $-1 \pm 0$ & $0 \pm 0$ \\
WW & $1 \pm 1$ & $-3 \pm 1$ & $2 \pm 0$ \\
CDW & $14 \pm 2$ & $-19 \pm 4$ & $17 \pm 4$ \\
WSDW & $9 \pm 2$ & $-14 \pm 3$ & $14 \pm 4$ \\
WSBW & $0 \pm 0$ & $-0 \pm 0$ & $3 \pm 1$ \\
Full depth & $24 \pm 4$ & $-38 \pm 8$ & $37 \pm 9$ \\
\hline
\end{tabular}

${ }^{\mathrm{a}}$ The station pairs over which the transport of these fronts is integrated are given in brackets. 


\begin{tabular}{|c|c|c|c|c|c|}
\hline Water Mass & Hesperides M.(16-18) & Orkney P. (24-33) & Bruce P. (38-41) & Discovery P. (47-51) & $S S R+W F(1-64$ \\
\hline SW & $0 \pm 0$ & $0 \pm 0$ & $-0 \pm 0$ & $0 \pm 0$ & $-1 \pm 0$ \\
\hline WW & $-1 \pm 0$ & $1 \pm 0$ & $-0 \pm 0$ & $0 \pm 0$ & $-7 \pm 1$ \\
\hline CDW & $-3 \pm 2$ & $2 \pm 3$ & $0 \pm 4$ & $4 \pm 1$ & $-12 \pm 5$ \\
\hline WSDW & $0 \pm 1$ & $-4 \pm 1$ & $-1 \pm 1$ & $-1 \pm 0$ & $-17 \pm 4$ \\
\hline WSBW & $0 \pm 0$ & $0 \pm 0$ & $0 \pm 0$ & $0 \pm 0$ & $-2 \pm 1$ \\
\hline Full depth & $-4 \pm 3$ & $-1 \pm 4$ & $-1 \pm 5$ & $3 \pm 2$ & $-40 \pm 9$ \\
\hline
\end{tabular}

${ }^{\text {a }}$ The station pairs over which the transport of these fronts is integrated are given in brackets.

heat budget of the gyre. The majority of the heat entering the gyre does so in association with the mean and eddy-induced southward (northward) transport of relatively warm (cold) CDW (WSDW and WSBW), with surface waters contributing a modest northward heat flow. A further notable factor in the heat budget of the gyre is the export of sea ice out of the Weddell Sea, which contributes $5 \pm 1$ TW (southward).

The southward transport of heat is diminished by the loss of $10 \pm 1$ TW of oceanic heat (equivalent to $2 \pm 0$ $\mathrm{W} \mathrm{m}^{-2}$ ) within the main box, consistent with the aforementioned net sea ice production in that area. However, the bulk of the heat entering the gyre across the ANDREX/I6S section (specifically, $26 \pm 13 \mathrm{TW}$ ) penetrates into the gyre's southwestern corner across the SR4 section, with contributions of $23 \pm 13$ TW and $3 \pm 1$ TW from the ocean circulation and sea ice, respectively. This implies that a considerably more intense rate of heat loss $\left(14 \pm 6 \mathrm{~W} \mathrm{~m}^{-2}\right)$ occurs south of the SR4 transect than in the gyre interior. Unlike in the ANDREX/I6S section, the bulk of the heat transport across the SR4 transect is effected by the ASF along the continental slope, suggesting that relatively warm CDW is entrained into the ASF via the recirculation in the central Weddell Sea.

\subsection{Freshwater Budget}

The freshwater budget of the Weddell Gyre is assessed by calculating freshwater transports across the boundaries of the model domain as in Tsubouchi et al. [2012]. The gyre is found to export $51 \pm 23 \mathrm{mSv}$ of
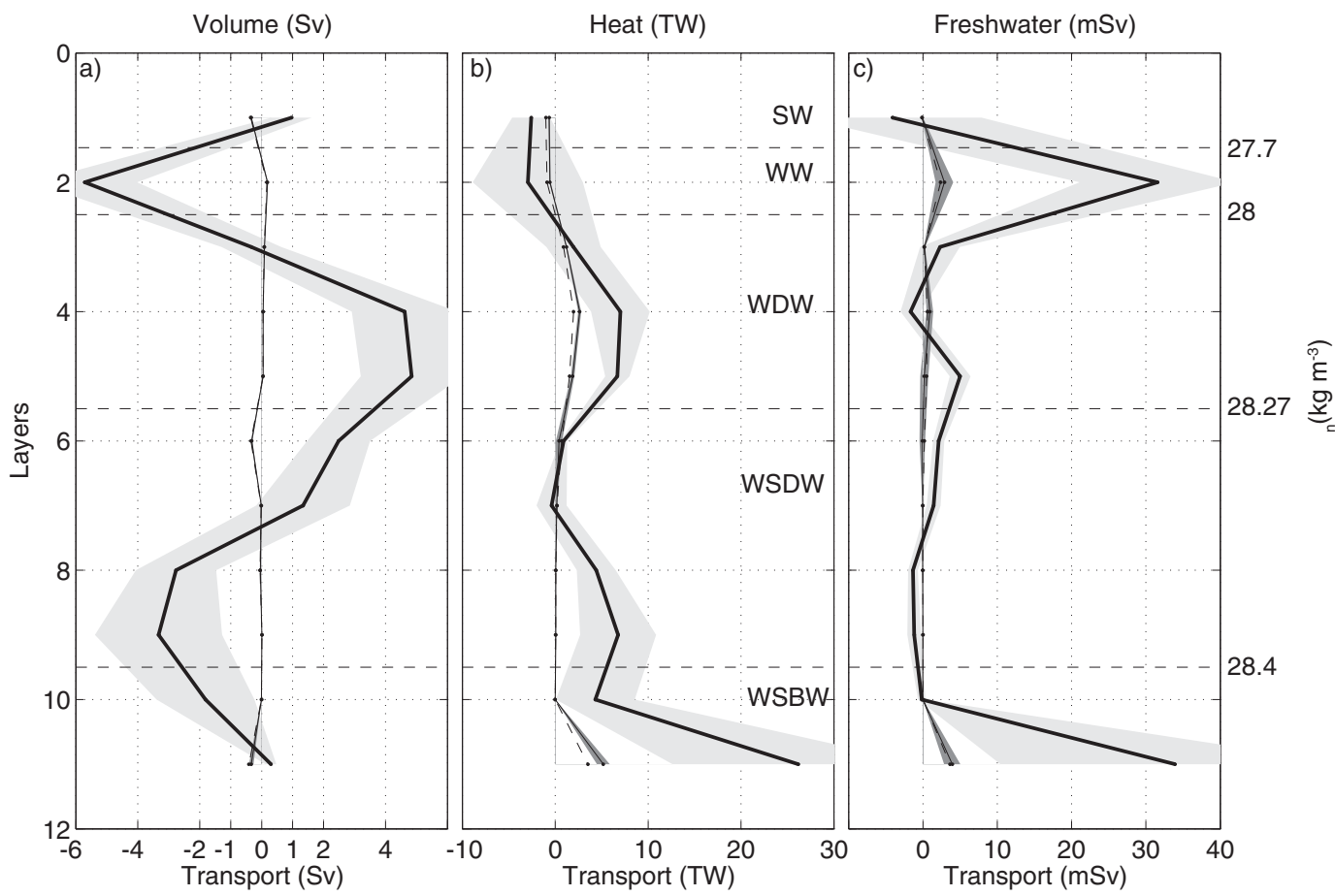

Figure 5. Net (a) Volume, (b) heat, and (c) freshwater mean (thick black line) versus eddy (thin black line) transports across the ANDREX/I6S section. Positive transports are directed into the box (southward). Gray envelopes represent one standard deviation uncertainties. 

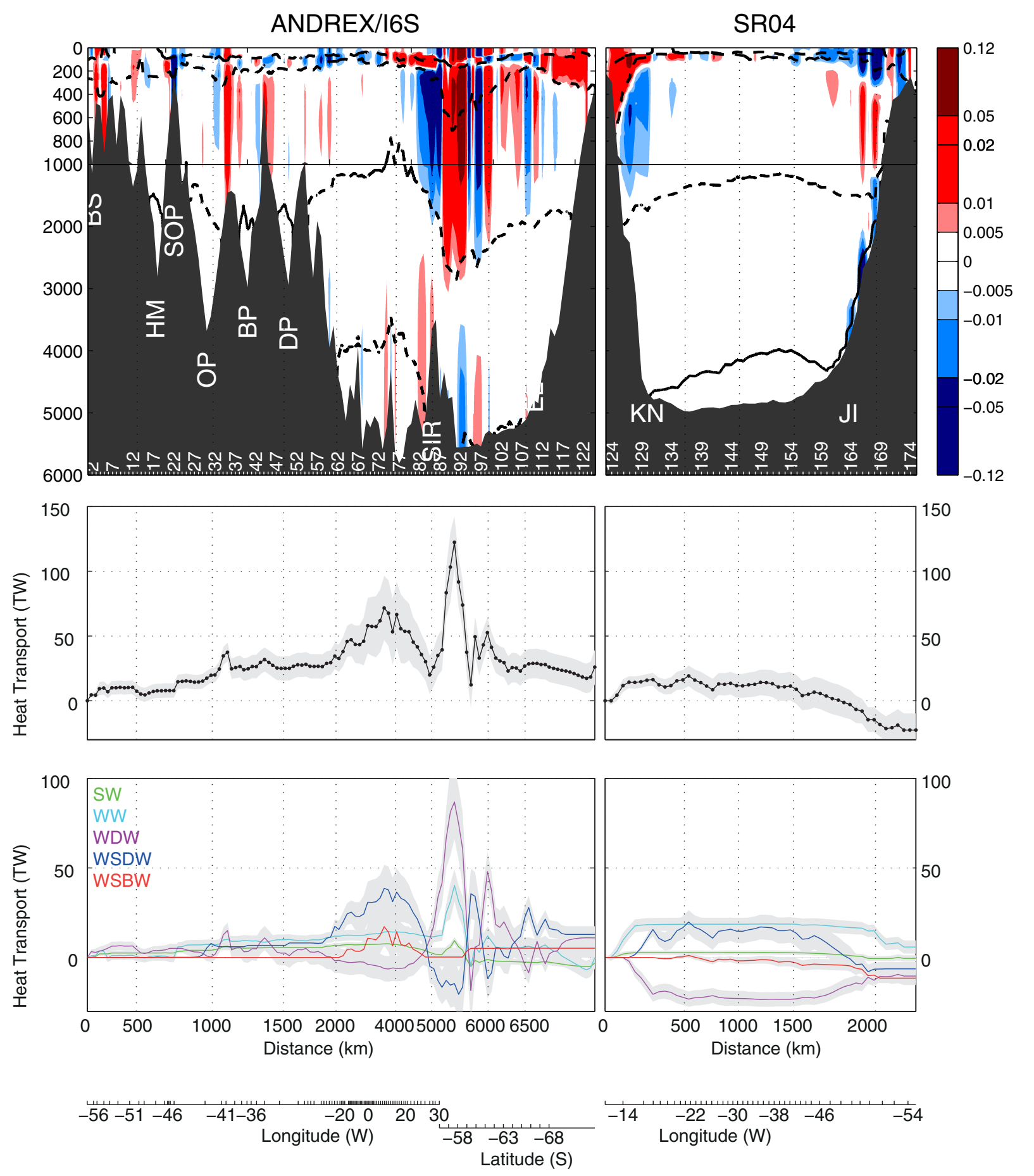

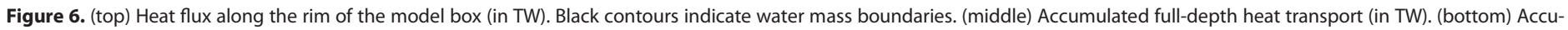
mulated heat transport (in TW) of individual water masses, as labeled.

freshwater to the midlatitude Southern Ocean across the ANDREX/I6S section, of which $38 \pm 23 \mathrm{mSv}$ are exported in liquid form ( $34 \pm 4 \mathrm{mSv}$ by the mean circulation and $4 \pm 1 \mathrm{mSv}$ by eddy-induced fluxes) and $13 \pm 1 \mathrm{mSv}$ in sea ice (note that the sea ice-mediated freshwater transport is not equal to the sea ice volume transport due to the presence of salt in sea ice). This net freshwater export is supplied by a matching meteoric input to the ocean within the gyre. In the SW box, $22 \pm 3 \mathrm{mSv}$ of meteoric water is added and exported northward across SR4 ( $13 \pm 13 \mathrm{mSv}$ and $9 \pm 3 \mathrm{mSv}$ in liquid and sea ice forms, respectively). An additional $28 \pm 4 \mathrm{mSv}$ is supplied by addition of meteoric water within the main box. 
A general feature of the freshwater budget of the Weddell Gyre is that freshwater transports are dominated by the circulation of the surface layers (SW and WW), where most of the sea ice production and melt and meteoric inputs of precipitation and glacial freshwater take place (Figure 7). A prevalence of precipitation over glacial sources in determining the meteoric freshwater input is suggested by a comparison of state-ofthe-art estimates of precipitation and ice mass loss in the Weddell Sea, which indicate values on the order of $50 \mathrm{mSv}$ [Lenaerts and van den Broeke, 2012] and $10 \mathrm{mSv}$ [Rignot et al., 2008], respectively. The inversion reduces the volume of precipitation within the model domain to $28 \pm 4 \mathrm{mSv}$ (cf. $49 \pm 25 \mathrm{mSv}$ a priori, Table 5). While the posterior meteoric input in the box is within prior uncertainties, the model suggests lower precipitation than that found in atmospheric reanalyses. Note, however, that the extent to which icebergs or precipitation falling on sea ice may be exported from the gyre before melting is not considered here. A final point of note is that the eddy-induced transport of freshwater across the gyre boundary is modest in comparison with the eddy heat flux (Figure 5c), most likely because eddy exchanges occur primarily at the gyre's northeastern edge, away from the main areas of sea ice production, precipitation, and glacial runoff.

\section{The Vertical Circulation of the Weddell Gyre}

\subsection{Overturning Circulation}

The diapycnal overturning circulation of the Weddell Gyre is found to consist of a double cell, the upper and lower branches of which are localized in distinct regions (Figure 8). A total of $13 \pm 4$ Sv of CDW and the classes of WSDW lighter than $\gamma^{n}=28.35 \mathrm{~kg} \mathrm{~m}^{-3}$ flow into the gyre across the ANDREX/16S section, and are returned equatorward as denser WSDW and WSBW ( $8 \pm 2 \mathrm{~Sv}$ ) and as upper-ocean waters lighter than $\gamma^{n}=$ $28.00 \mathrm{~kg} \mathrm{~m}^{-3}(5 \pm 2 \mathrm{~Sv})$.

The upper limb, the upwelling of CDW into the WW layer $(2 \pm 2 \mathrm{~Sv}$, equivalent to an upwelling rate of $6.3 \pm 4.5 \times 10^{-7} \mathrm{~ms}^{-1}$ ) occurs in the gyre interior (Figure 9), whereas the bulk of the downwelling leading to AABW formation ( $6 \pm 2 \mathrm{~Sv}$ ) takes place near the gyre's southwestern edge, south of the SR4 section (Figure 8 , left plot). Within the gyre interior, upwelling is accompanied by a transformation of CDW into the lightest WSDW class ( $2 \pm 1 \mathrm{~Sv}$, equivalent to a downwelling rate of $6.5 \pm 4.5 \times 10^{-7} \mathrm{~ms}^{-1}$ ). As a consequence, the CDW and light WSDW inflow to the gyre is diminished to $6 \pm 2 \mathrm{~Sv}$ across the SR4 transect, although this is partially compensated by the reversal of the near-surface flow in the SW box underpinning a poleward transport of $2 \pm 1 \mathrm{~Sv}$ of those waters across that section. This results in a single-celled overturning circulation of $8 \pm 2 \mathrm{~Sv}$ across the SR4 transect.

Note that half of the $4 \pm 1$ Sv of WSBW entering the model domain across the SR4 section ( $2 \pm 1 \mathrm{~Sv})$ upwells diapycnally into WSDW at a rate of $7.3 \pm 6.6 \times 10^{-7} \mathrm{~ms}^{-1}$ before leaving the Weddell Gyre (Figure 9), likely because of entrainment as WSBW cascades down the continental slope of the Antarctic Peninsula. In contrast, the lighter classes of WSDW experience diapycnal downwelling at a rate of $5.6 \pm 4.8 \times 10^{-7} \mathrm{~ms}^{-1}$ within the gyre interior (Figure 9), consistent with densification of WSDW by diapycnal mixing with WSBW.

\subsection{Water Mass Transformation}

A more complete perspective of the water mass transformations implicit in the overturning circulation of the Weddell Gyre may be obtained by examining the $\theta$-S volumetric transport diagrams in Figure 10 . The volume transports across the model boundaries (i.e., the ANDREX/I6S and SR4 transects, which bound the gyre interior) and across the inner gyre boundary of the model domain (i.e., the SR4 section, which bounds the SW box) are mapped to $\theta$-S space, using bins of $\delta \theta=0.02$ and $\delta S=0.01$. For each $\theta$-S bin, the volume transport that occurs within that thermohaline class across the pertinent section(s) is integrated. Thus, positive (negative) values in the diagrams indicate that there is an excess of water with those thermohaline properties flowing out of (into) the control volume in each diagram. The choice of control volumes allows us to distinguish between the water mass transformations occurring in the gyre interior and those near the gyre's southwestern boundary.

The left plot in Figure 10 reveals that a consumption of the warmest and saltiest CDW and the WSDW warmer than approximately $-0.5^{\circ} \mathrm{C}$ takes place in the SW box. This is balanced primarily by a production of colder WSDW and WSBW, associated with the diapycnal downwelling characterized above, and of a relatively cool and fresh variety of CDW, which is likely a result of the ventilation of CDW by shelf waters cascading down the continental slope of the southwestern and western Weddell Sea. Following these 

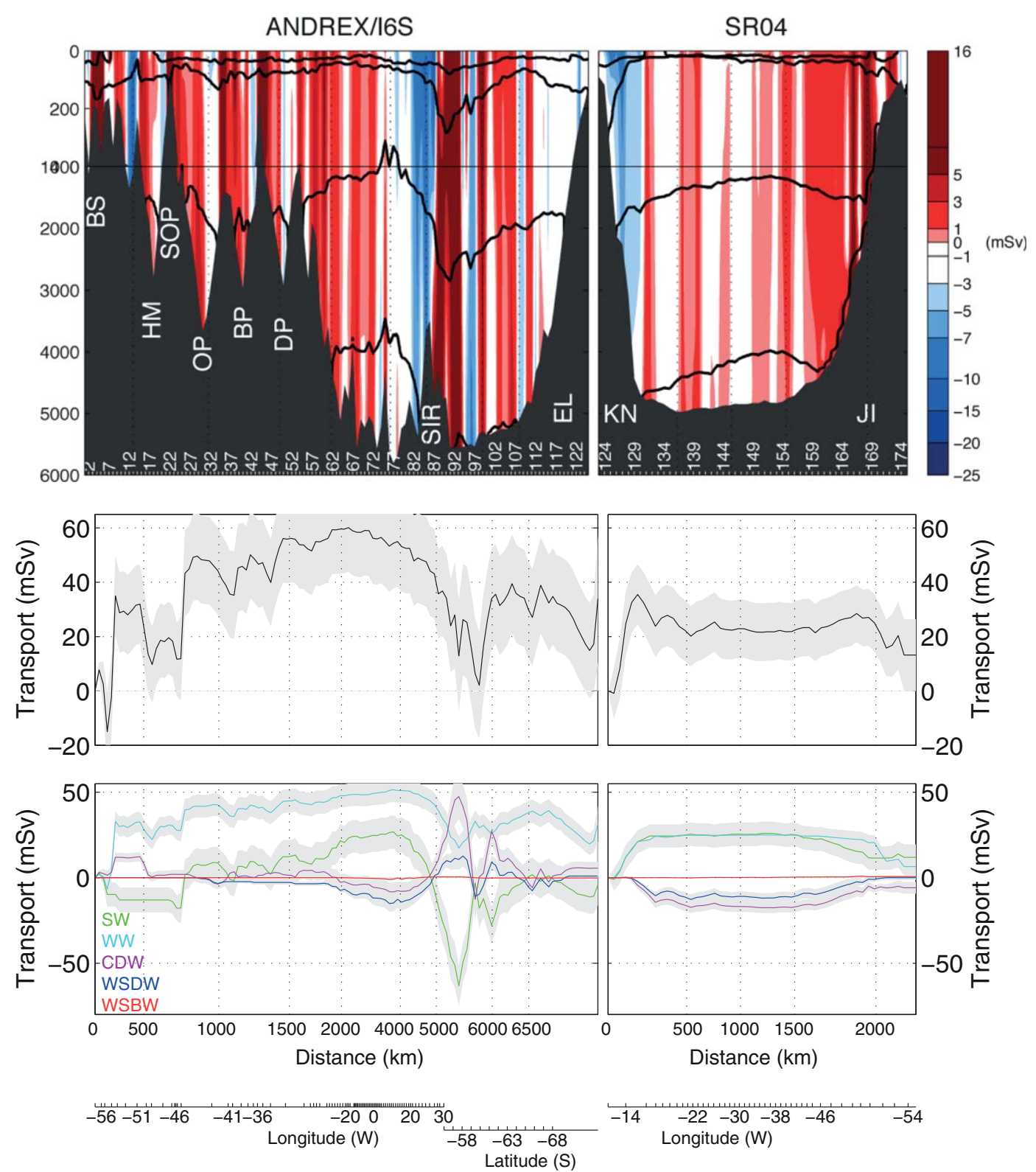

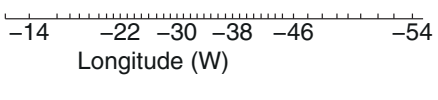

Figure 7. (top) Freshwater flux along the rim of the model box (in mSv). Black contours indicate water mass boundaries. (middle) Accumulated full-depth freshwater transport (in mSv). (bottom) Accumulated freshwater transport (in mSv) of individual water masses, as labeled.

thermohaline changes, a net densification (by $0.028 \mathrm{~kg} \mathrm{~m}^{-3}$ ) of the waters circulating around the SW box occurs, visible in the translation to higher density of the transport-weighted mean $\theta$-S of the flow (inflow: $\theta=-0.222^{\circ} \mathrm{C}, \mathrm{S}=34.543, \gamma^{n}=27.942 \mathrm{~kg} \mathrm{~m}^{-3}$; outflow: $\left.\theta=-0.489^{\circ} \mathrm{C}, \mathrm{S}=34.553, \gamma^{n}=27.970 \mathrm{~kg} \mathrm{~m}^{-3}\right)$. This densification is equivalent to a rate of oceanic buoyancy loss of $1.6 \times 10^{-9} \mathrm{~m}^{2} \mathrm{~s}^{-3}$, which is supplied by oceanic heat loss $\left(1.3 \times 10^{-9} \mathrm{~m}^{2} \mathrm{~s}^{-3}\right)$, with the salinity increase due to sea ice production playing a secondary role $\left(0.3 \times 10^{-9} \mathrm{~m}^{2} \mathrm{~s}^{-3}\right)$.

A very different set of water mass transformations take place in the gyre interior (Figure 10, right plot). There is a net consumption of WSBW, indicative of diapycnal upwelling, and of several classes of CDW (most clearly, those in the range $0.1<\theta<0.7^{\circ} \mathrm{C}$ ). This is balanced by a production of the denser classes of WSDW (linked to the upwelling of WSBW and downwelling of dense CDW into WSDW), a cool and fresh variety of CDW with potential temperature near $0^{\circ} \mathrm{C}$, and several types of pycnocline and surface waters lighter than $\gamma^{n}=28.0 \mathrm{~kg}$ $\mathrm{m}^{3}$. The cool and fresh variety of CDW appears primarily in the vicinity of the ASF over the South Scotia Ridge 

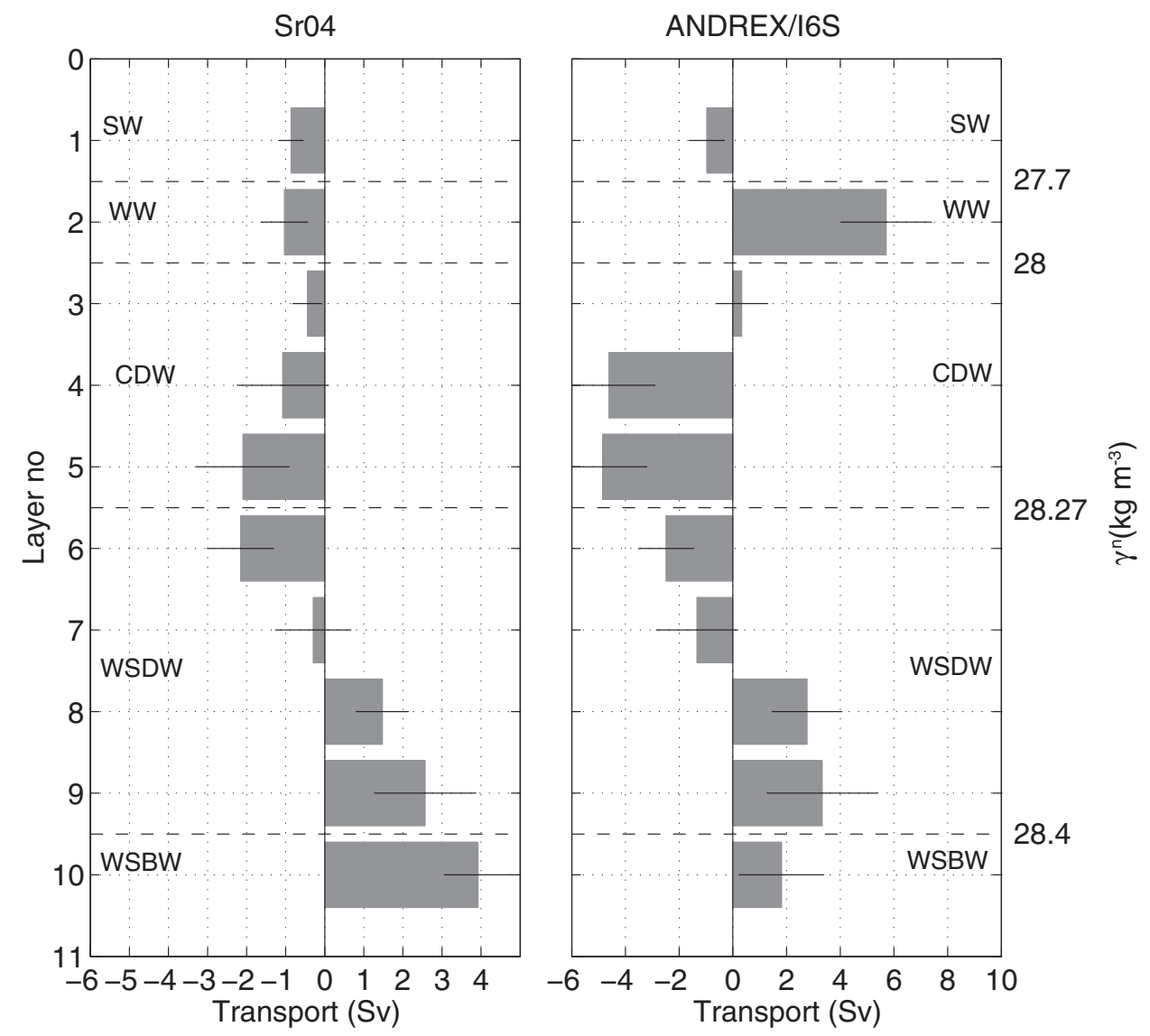

Figure 8. Overturning circulation (defined the volume transport divergence for each coast-to-coast section) across the (left) SR4 and (right) ANDREX/16S transects. Positive values are directed northward. Horizontal dashed lines indicate water mass boundaries as defined in Table 3.

(Figure 2), suggesting that it is formed through ventilation of CDW by relatively light shelf waters in the northern Antarctic Peninsula [Whitworth et al., 1994]. While it is not possible to ascertain the processes which underpin the production of pycnocline and surface waters, diapycnal upwelling across the base of the winter mixed layer in the gyre interior (see section $5 \mathrm{a}$ ) is likely to play a major role. Overall, the oceanic buoyancy loss in the region is modest $\left(3.5 \times 10^{-10} \mathrm{~m}^{2} \mathrm{~s}^{-3}\right)$, as oceanic cooling and sea ice production are counteracted by a net meteoric input. The waters circulating around the gyre interior experience a cooling of $0.01^{\circ} \mathrm{C}$ and a freshening of 0.018 , leading to a small densification of $0.007 \mathrm{~kg} \mathrm{~m}^{-3}$ (inflow: $\theta=0.192^{\circ} \mathrm{C}, \mathrm{S}=34.545, \gamma^{n}=27.860 \mathrm{~kg} \mathrm{~m}^{-3}$; outflow: $\theta=0.182^{\circ} \mathrm{C}, \mathrm{S}=34.527, \gamma^{n}=27.867 \mathrm{~kg} \mathrm{~m}^{-3}$ ).

\section{Discussion}

The diagnosed circulation of the Weddell Gyre reproduces well-known qualitative features of the regional flow, and adds significant new quantitative information. The gyre is estimated to transport ca. 40-50 Sv cyclonically around the Weddell-Enderby Basin and to exhibit modest recirculation near the Prime Meridian, in line with the findings of studies based on direct velocity measurements and general circulation models [Fahrbach et al., 1994; Beckmann et al., 1999; Klatt et al., 2005; Schröder and Fahrbach, 1999]. Along the gyre's southern and western flanks, more than $80 \%$ of the gyre transport is concentrated near the continental boundary, at the ASF, as previously noted by Klatt et al. [2005]. This frontal jet disintegrates as the gyre flows over the complex topography around the northern tip of the Antarctic Peninsula and the South Scotia Ridge, resulting in a broadening of the gyre's northern limb over an extensive region spanning the ridge and the northern edge of the Weddell-Enderby Basin [Heywood et al., 2004]. An important, little appreciated feature of the Weddell Gyre evident in our diagnostics is that it hosts a substantial throughflow component. This entails a net import of $13 \pm 4$ Sv across the gyre's eastern edge from the Indian sector of the subpolar 


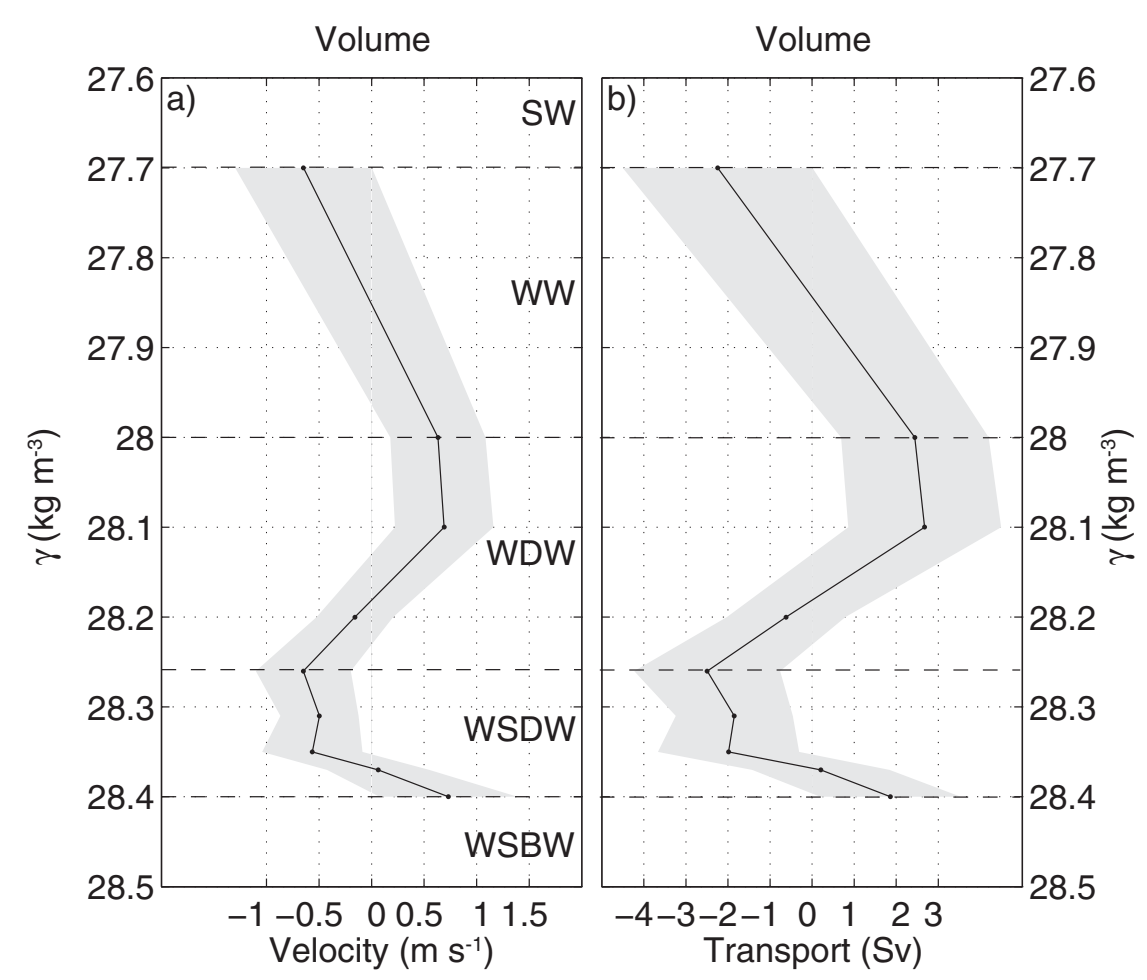

Figure 9. (a) Diapycnal velocities for volume across the model layer interfaces. (b) Corresponding diapycnal transports of volume. In all plots, positive values are directed toward lighter layers. Gray envelopes represent one standard deviation uncertainties. Horizontal dashed lines indicate water mass boundaries as defined in Table 3.

Southern Ocean, in association with the ASF, and a net export of the same value across the gyre's northern edge, following the ASF's disintegration.

The heat budget of the Weddell Gyre qualitatively agrees with previous estimates based on different methods and data sets [Fahrbach et al., 1994; Klatt et al., 2005]. The ACC is found to inject heat to the gyre at a rate of $36 \pm 13 \mathrm{TW}$, primarily along the gyre's northern and eastern edges and in part via eddy exchanges (14\%) [cf. Schröder and Fahrbach, 1999] and mobile sea ice export (14\%). The heat transport across the eastern rim of the gyre $(9 \pm 13$ TW) is weaker than the net southward heat flux across the SR4 section ( $26 \pm 3$ TW), because most of the heat enters the gyre through its northern rim [cf. Klatt et al., 2005]. Our diagnosed heat flux across the SR4 transect is significantly lower than that of Fahrbach et al. [1994], who estimated it as 35 TW from CTD and current meter data but agrees well with Yaremchuk et al. [1998] who found 28 PW based on an inverse model of an earlier occupation of the SR4 section.

The gyre exports $51 \pm 23 \mathrm{mSv}$ of freshwater toward the midlatitude Southern Ocean, mainly across the South Scotia Ridge (Figure 7). The $22 \pm 13 \mathrm{mSv}$ supplied by the inner gyre across the SR4 section is supplemented by $27 \pm 4 \mathrm{mSv}$ of meteoric water input to the main box. Our diagnosed sea ice-mediated freshwater export from the inner gyre $\left(315 \pm 32 \mathrm{~km}^{3} \mathrm{yr}^{-1}\right)$ is lower than the prior estimate based on the literature, but not significantly so within uncertainties. For example, the modeling studies of Petty et al. [2013] and Haid and Timmermann [2013] find respective freshwater exports in sea ice form from the southwestern Weddell Sea of $690 \pm 243 \mathrm{~km}^{3} \mathrm{yr}^{-1}$ and $993 \mathrm{~km}^{3} \mathrm{yr}^{-1}$, and Drucker et al. [2011] estimate $390 \pm 130$ $\mathrm{km}^{3} \mathrm{yr}^{-1}$ from satellite images. One possible explanation for our comparatively weak sea ice export is that, as our sections are summer-biased, the ocean contains more meltwater than at other times of year, and therefore requires a relatively low flow of sea ice to balance the addition of meteoric water south of the SR4 transect. A second plausible explanation relates to the lack of winter sea ice thickness measurements in the ASPeCt data base, which may lead to an underestimation of the annual-mean sea ice thickness.

In the preceding characterization of the Weddell Gyre, two factors are key in determining the nature of the overturning circulation and water mass transformations in the gyre: (1) the concentration of oceanic heat 


\section{QAGU Journal of Geophysical Research: Oceans}

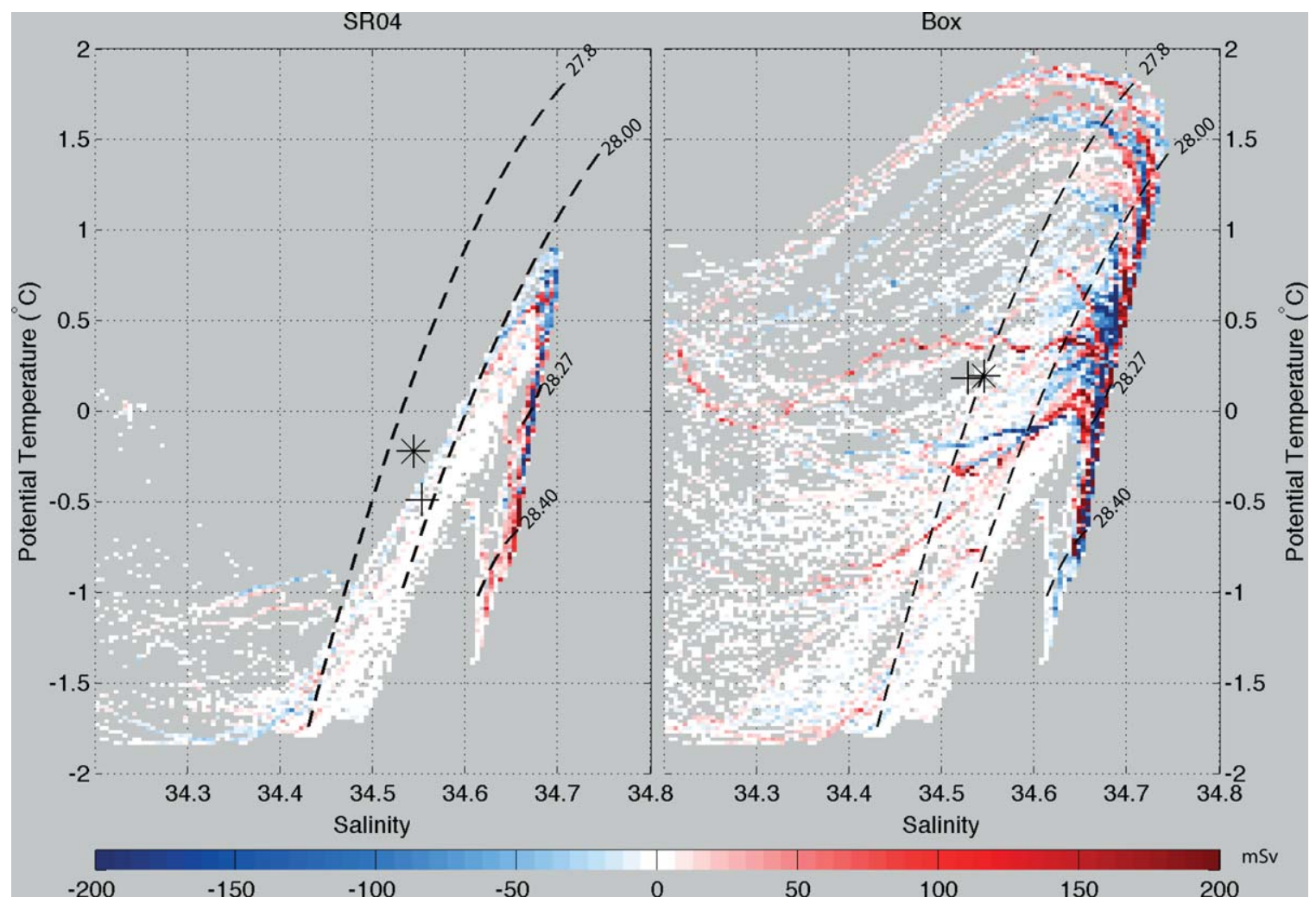

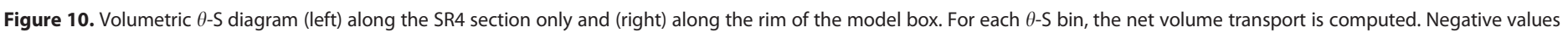

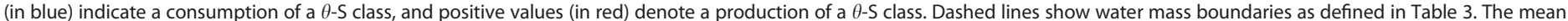
volume-transport-weighted $\theta$-S of the inflow and outflow are, respectively, marked as black asterisks and crosses.

loss in the SW box region and (2) the existence of a significant throughflow component to the gyre. The overturning circulation of the gyre has an asymmetric double-cell structure, with diapycnal upwelling of $2 \pm 2$ Sv of CDW across the winter mixed layer base in the gyre interior, and comparatively stronger downwelling of $8 \pm 2 \mathrm{~Sv}$ across the intermediate classes of WSDW $\left(\gamma^{n}=28.35 \mathrm{~kg} \mathrm{~m}^{-3}\right)$ near the western/southwestern boundary. While the occurrence of a double-celled overturning with upwelling in the gyre interior is expected from the structure of the wind-forced Ekman vertical motion in a cyclonic gyre [Sverdrup, 1947], the strong bias toward and localization of downwelling arises from factor (1) above, which leads to intense buoyancy loss (through cooling) in the SW box.

Our results suggest that the CDW upwelling across the permanent pycnocline of the Weddell Gyre interior is exported both toward the north, into the ACC (at a rate of $5 \pm 1 \mathrm{~Sv}$, and toward the western and southwestern edge of the Weddell Sea $(2 \pm 1 \mathrm{~Sv})$, where it is implicated in the strong near-boundary downwelling. Observational evidence of downwelling and AABW formation at rates comparable to ours (6 $\pm 2 \mathrm{~Sv}$ ) along the slope region of the western and southwestern Weddell Gyre is abundant, and there are some indications in the literature of midgyre upwelling in line with our diagnostics too (e.g., estimated upwelling rates of $5.4 \times 10^{-7} \mathrm{~m} \mathrm{~s}^{-1}$ [Gordon et al., 1984] and $1.4 \times 10^{-6} \mathrm{~m} \mathrm{~s}^{-1}$ [Gordon and Huber, 1990], and an upwelling transport of $1.9 \mathrm{~Sv}$ [Hoppema et al., 1999]). However, the connection between upwelling and downwelling in the gyre and their integration into a double-celled overturning circulation seem to have gone largely unnoticed to date.

A further important feature of the water mass transformation in the Weddell Gyre is underpinned by factor (2) above. Specifically, the import of waters from the Indian sector across the gyre's eastern edge injects ACC-sourced CDW and an Indian-sourced variety of AABW (within the WSDW density class) to the gyre at respective rates of $14 \pm 2$ and $9 \pm 2$ Sv. The former water mass supplies the upwelling limb and contributes significantly to the downwelling limb of the overturning circulation of the gyre 


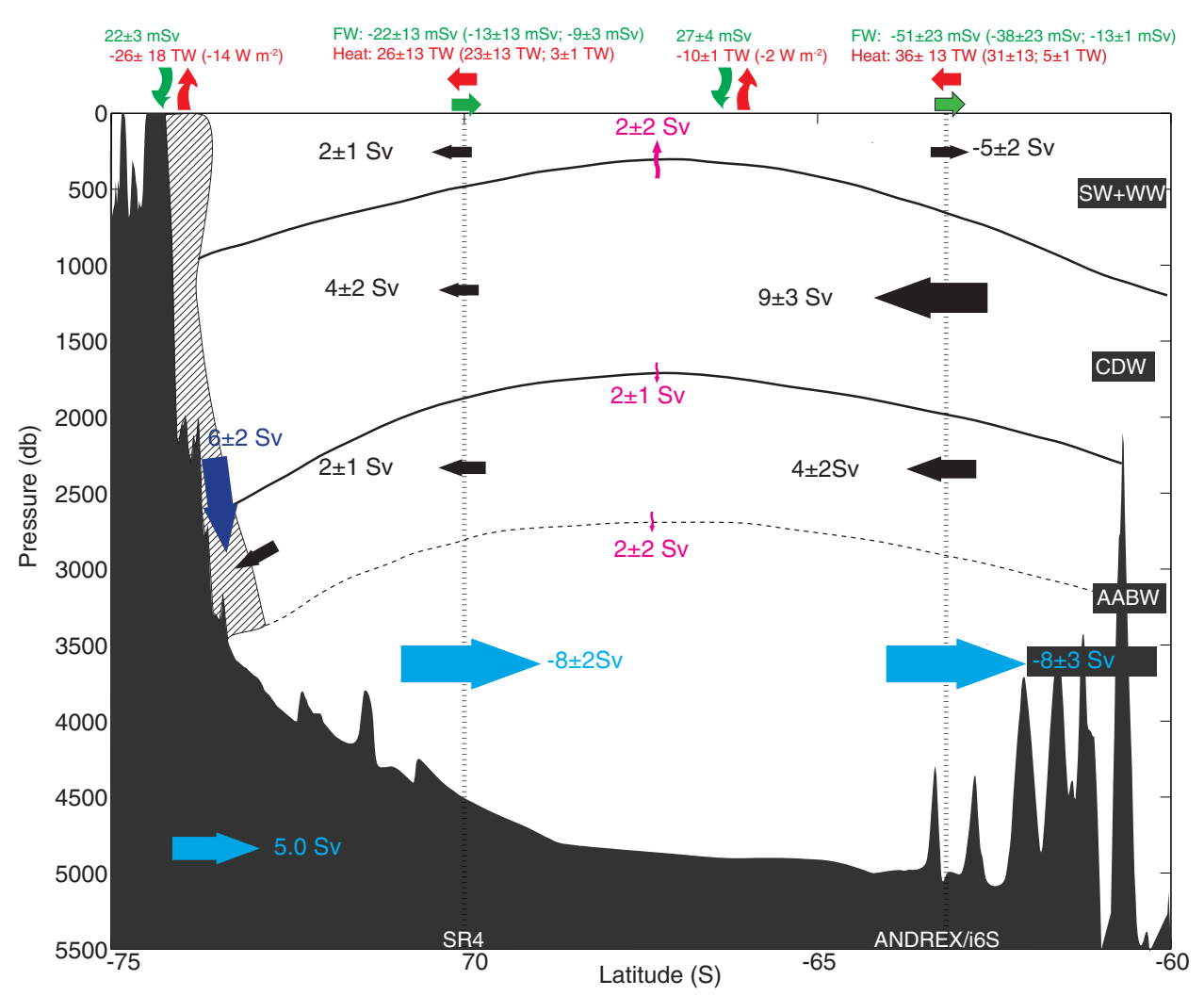

Figure 11. Schematic of the overturning circulation, heat and freshwater budgets of the Weddell Gyre. The main water masses are represented and separated by the horizontal solid black contours. The ANDREX/I6S and SR4 sections are indicated as dotted vertical lines. Westward-/southward-flowing layers, shown as black arrows, are separated from the northward-flowing layers, represented by the blue arrows, by the horizontal dashed contour. The diapycnal fluxes are shown in magenta and the transformation of deep and surface water in bottom water in dark blue. Air-sea and full-depth fluxes of heat and freshwater are indicated as red and green arrows at the surface, respectively. The fluxes are partitioned into oceanic (first term in brackets) and mobile sea ice (second term in brackets) components. The hatched region represents the AABW formation processes in the SW box.

[Nicholls et al., 2009]. Additionally, it sustains the export across the gyre's northern edge of $10 \pm 4$ Sv of a distinctively cooler and fresher CDW (Table 7) type produced by mixing with shelf waters cascading downslope around the continental boundaries of the gyre. This CDW type plays a major role in the ventilation of the deep layers of the ACC in the South Atlantic [Whitworth et al., 1994; Naveira Garabato et al., 2002a].

Most remarkably, the import of AABW from the Indian sector makes up as much as $\sim 30 \%$ of the $8 \pm 2 \mathrm{~Sv}$ of AABW exported from the Weddell Gyre. The Indian-sourced AABW enters the gyre primarily in the 28.27 $<\gamma^{n}<28.35 \mathrm{~kg} \mathrm{~m}^{-3}$ density class (model layers 6 and 7, Figure 8), and is found to feed the net production of $6 \pm 2$ Sv of denser WSDW ( $28.35<\gamma^{n}<28.40 \mathrm{~kg} \mathrm{~m}^{-3}$, model layers 8 and 9) and WSBW within the gyre. Thus, while the gyre plays a prominent role in the export of AABW to the midlatitude Southern Ocean, contributing close to half of the net circumpolar export [Naveira Garabato et al., 2013], our results suggest that its standing in net AABW formation (defined as the downward diapycnal volume transport across the $\gamma^{n}=28.27 \mathrm{~kg} \mathrm{~m}^{-3}$ surface) is more modest than previously thought. However, the intense oceanic buoyancy loss occurring in the SW box results in the ventilation and densification of all the interior water masses entering the gyre's eastern edge (not solely CDW), effectively leading to the recycling of the Indian-sourced AABW into a cooler, fresher and denser Weddell variety of AABW. Some of this AABW (WSBW) must then upwell diapycnally within the gyre to be exported to the midlatitudes as WSDW. The occurrence of a significant influx of Indian-sourced AABW to the Weddell Gyre has been reported in several transient tracer-based investigations [Archambeau et al., 1998; Meredith et al., 2000; Hoppema et al., 2001] and in a numerical modeling study [Schodlok et al., 2002], and its formation traced to the Prydz Bay/Cape Darnley polynya region [see Couldrey et al., 2013; Ohshima et al., 2013]. 


\section{QAGU Journal of Geophysical Research: Oceans}

\section{Synthesis}

The circulation of the Weddell Gyre diagnosed in this study is characterized schematically in Figure 11. CDW and light WSDW enter the gyre across its eastern boundary. In the gyre interior, the inflowing water is consumed by upwelling, forming the upper-cell of the Weddell overturning. The remaining CDW and light WSDW, as well as upper-ocean waters produced by midgyre upwelling, enter the southwestern Weddell Sea, where they are ventilated and transformed into denser WSDW and WSBW, forming the lower cell of the Weddell overturning.

Our findings suggest several significant revisions to present views of the role of the Weddell Gyre in closing the lower limb of the GOC. Of paramount importance amongst these are the asymmetric, double-celled structure of the overturning in the gyre, linked to wind-driven midgyre upwelling and intense oceanic buoyancy loss near the gyre's western and southwestern boundary; and the existence of a significant throughflow component to the gyre, via which CDW and AABW are imported from the Indian sector, ventilated and densified in the inner Weddell Sea, and exported to the midlatitude Southern Ocean across the gyre's northern edge. This implies that the prominence of the Weddell Gyre in exporting AABW to and ventilating the deep layers of the midlatitude Southern Ocean stems in part from the influx of remotely formed water masses from the Indian sector.

We conclude that, if efforts to monitor and understand the Weddell Gyre's contribution to global-scale overturning and deep-ocean ventilation are to provide a balanced view of the gyre's climatic evolution and its drivers, they cannot focus solely on the sites of intense densification and AABW export, as they have largely done to date, but must also capture midgyre upwelling processes and the inflows from the Indian sector across the gyre's eastern rim. In the latter case, there are recent indications that decadal-scale changes in the Indian-sourced inflows are beginning to perturb significantly the circulation of the gyre [Couldrey et al., 2013].

\section{Acknowledgments}

The ANDREX project was supported by the National Environmental Research Council (NE/E01366X/1). L.J. also acknowledges financial support from NSF (OCE-1231803). We thank Matthew Mazloff (Scripps Institution of Oceanography) for providing the SOSE output and Takamasa Tsubouchi for many insightful discussions on inverse modeling. It is a great pleasure to acknowledge the outstanding contribution of the Masters, officers and crew of RRS James Clark Ross, RRS James Cook, RV Roger Revelle and PFS Polarstern, as well as the many scientists who participated in the data collection and processing. We thank two anonymous reviewers whose comments greatly improved the clarity of the manuscript. This work is dedicated to the memory of Eberhard Fahrbach, a great polar scientist and mentor whose legacy in polar oceanography will carry on for the years to come.

\section{References}

Archambeau, A., C. Pierre, A. Poisson, and B. Schauer (1998), Distributions of oxygen and carbon stable isotopes and CFC-12 in the water masses of the Southern Ocean at $30^{\circ}$ E from South Africa to Antarctica: Results of the CIVA1 cruise, J. Mar. Syst., 17, 25-38.

Bacon, S., and L. Jullion (2011), RRS James Cook: Antarctic Deep Water Rates of EXport (ANDREX), Tech. Rep. 08, Natl. Oceanogr. Cent, Southampton, U. K.

Beckmann, A., H. Hellmer, and R. Timmermann (1999), A numerical model of the Weddell Sea: Large-scale circulation and water mass distribution, J. Geophys. Res., 104(C10), 23,375-23,391.

Carmack, E., and T. Foster (1975), Flow of water out of the Weddell Sea, Deep Sea Res. Oceanogr. Abstr., 22(11), 711-724.

Cavalieri, D., C. Parkinson, P. Gloersen, and H. J. Zwally (1996), Sea ice concentrations from nimbus-7 SMMR and DMSP SSM/I-SSMIS passive microwave data, technical report, Natl. Snow and Ice Data Cent., Boulder, Colo.

Couldrey, M., L. Jullion, A. C. Naveira Garabato, C. Rye, L. Herráiz-Borreguero, P. J. Brown, M. P. Meredith, and K. G. Speer (2013), Remotely induced warming of Antarctic Bottom Water in the eastern Weddell Gyre, Geophys. Res. Lett., 40, 1-6, doi:10.1002/grl.50526.

Drucker, R., S. Martin, and R. Kwok (2011), Sea ice production and export from coastal polynyas in the Weddell and Ross Seas, Geophys. Res. Lett., 38, L17502, doi:10.1029/2011GL048668.

Fahrbach, E. (2005), Expedition FS Polarstern ANT-XXII/3, Tech. Rep. 533, Alfred Wegener Inst. für polar und Meeresforschung in der Helmholtz-Gemeinschaft, Bremerhaven, Germany.

Fahrbach, E., M. Knoche, and G. Rohardt (1991), An estimate of water mass transformation in the southern Weddell Sea, Mar. Chem., 25-44(1-4), 515-538.

Fahrbach, E., G. Rohardt, M. Schröder, and V. Strass (1994), Transport and structure of the Weddell Gyre, Ann. Geophys., 12(9), $840-855$.

Fahrbach, E., G. Rohardt, N. Scheele, M. Schröder, V. Strass, and A. Wisotzki (1995), Formation and discharge of deep and bottom water in the northwestern Weddell Sea, J. Mar. Res., 53(4), 515-538.

Fahrbach, E., S. Harms, G. Rohardt, M. Schroder, and R. Woodgate (2001), Flow of bottom water in the northwestern Weddell Sea, J. Geophys. Res., 106(C2), 2761-2778.

Fahrbach, E., M. Hoppema, G. Rohardt, O. Boebel, O. Klatt, and A. Wisotzki (2011), Warming of deep and abyssal water masses along the Greenwich Meridian on decadal time scales the Weddell Gyre as a heat buffer, Deep Sea Res., Part II, 58(25-26), 2509-2523, doi:10.1016/ j.dsr2.2011.06.007.

Foldvik, A., T. Gammelsrød, S. Østerhus, E. Fahrbach, G. Rohardt, M. Schröder, K. W. Nicholls, L. Padman, and R. Woodgate (2004), Ice shelf water overflow and bottom water formation in the southern Weddell Sea, J. Geophys. Res., 109, C02015, doi:10.1029/2003JC002008.

Foster, T., and E. Carmack (1976), Frontal zone mixing and Antarctic Bottom Water formation in the southern Weddell Sea, Deep Sea Res. Oceanogr. Abstr., 23(4), 301-317.

Ganachaud, A. (2003), Error budget of inverse box models: The North Atlantic, J. Atmos. Oceanic Technol., 20(11), 1641-1655.

Gill, A. (1973), Circulation and bottom water production in the Weddell Sea, Deep Sea Res. Oceanogr. Abstr., 20(2), 111-140.

Gordon, A. L. (1998), Western Weddell Sea thermohaline stratification, in Ocean, Ice, and Atmosphere: Interactions at the Antarctic Continental Margin, Antarct. Res. Ser., vol. 75, edited by S. S. Jacobs and R. F. Weiss, pp. 215-240, AGU, Washington, D. C., doi:10.1029/ AR075p0215.

Gordon, A. L., and B. A. Huber (1990), Southern Ocean winter mixed layer, J. Geophys. Res., 95(C7), 11,655-11,672.

Gordon, A. L., C. Chen, and W. G. Metcalf (1984), Winter mixed layer entrainment of Weddell Deep Water, J. Geophys. Res., 89(1), 637-640.

Gordon, A. L., M. Visbeck, and B. Huber (2001), Export of Weddell Sea deep and bottom water, J. Geophys. Res., 106(C5), 9005-9017. 
Gordon, A. L., B. Huber, D. Mckee, and M. Visbeck (2010), A seasonal cycle in the export of bottom water from the Weddell Sea, Nat. Geosci., 3(8), 551-556, doi:10.1038/ngeo916.

Gouretski, V. V., and A. I. Danilov (1993), Weddell Gyre: Structure of the eastern boundary, Deep Sea Res., Part I, 40(3), $561-582$.

Haid, V., and R. Timmermann (2013), Simulated heat flux and sea ice production at coastal polynyas in the southwestern Weddell Sea, J. Geophys. Res., 118(5), 2640-2652.

Harms, S., E. Fahrbach, and V. Strass (2001), Sea ice transports in the Weddell Sea, J. Geophys. Res., 106, 9057-9073.

Heywood, K. J., A. C. Naveira Garabato, D. P. Stevens, and R. Muench (2004), On the fate of the Antarctic Slope Front and the origin of the Weddell Front, J. Geophys. Res., 109, C06021, doi:10.1029/2003JC002053.

Hoppema, M., E. Fahrbach, M. H. Stoll, and H. J. de Baar (1999), Annual uptake of atmospheric $\mathrm{CO}_{2}$ by the Weddell Sea derived from a surface layer balance, including estimations of entrainment and new production, J. Mar. Res., 19(4), 219-233.

Hoppema, M., O. Klatt, W. Roether, E. Fahrbach, K. Bulsiewicz, C. Rodehacke, and G. Rohardt (2001), Prominent renewal of Weddell Sea Deep Water from a remote source, J. Mar. Res., 59(2), 257-279.

Hoppema, M., A. Velo, S. V. Heuven, and T. Tanhua (2009), Consistency of cruise data of the CARINA database in the Atlantic sector of the Southern Ocean, Earth Syst. Sci. Data, 1, 63-75, doi:10.3334/CDIAC/otg.CARINA.SO.V1.0.

Huhn, O., H. H. Hellmer, M. Rhein, C. Rodehacke, W. Roether, M. Schodlok, and M. Schroder (2008), Evidence of deep-and bottom-water formation in the western Weddell Sea, Deep Sea Res., Part II, 55(8-9), 1098-1116.

Jackett, D., and T. McDougall (1997), A neutral density variable for the world's oceans, J. Phys. Oceanogr., 27(2), $237-263$.

Jacobs, S. S. (2004), Bottom water production and its links with the thermohaline circulation, Antarct. Sci., 16(4), 427-437.

Kerr, R., K. J. Heywood, M. M. Mata, and C. A. E. Garcia (2012), On the outflow of dense water from the Weddell and Ross Seas in OCCAM model, Ocean Sci., 8(3), 369-388, doi:10.5194/os-8-369-2012.

Key, R., A. Kozyr, C. Sabine, K. Lee, R. Wanninkhof, J. Bullister, R. A. Feely, F. J. Millero, C. Mordy, and T. H. Peng (2004), A global ocean carbon climatology: Results from Global Data Analysis Project (GLODAP), Global Biogeochem. Cycles, 18, 1-23, doi:10.1029/2004GB002247.

Key, R. M., et al. (2010), The CARINA data synthesis project: Introduction and overview, Earth Syst. Sci. Data, 8, $105-122$.

Klatt, O., E. Fahrbach, M. Hoppema, and G. Rohardt (2005), The transport of the Weddell Gyre across the Prime Meridian, Deep Sea Res., Part II, 52(3-4), 513-528.

Lenaerts, J., and M. R. van den Broeke (2012), A new, high-resolution surface mass balance map of Antarctica (1979-2010) based on regional atmospheric climate modeling, Geophys. Res. Lett., 39, L04501, doi:10.1029/2011GL050713.

Lumpkin, R., and K. Speer (2007), Global ocean meridional overturning, J. Phys. Oceanogr., 37(10), 2550-2562.

Marinov, I., A. Gnanadesikan, J. R. Toggweiler, and J. L. Sarmiento (2006), The Southern Ocean biogeochemical divide, Nature, 441 (7096), 964-967.

Mazloff, M. R., P. Heimbach, and C. Wunsch (2010), An eddy-permitting Southern Ocean state estimate, J. Phys. Oceanogr., 40(5), 880-899, doi:10.1175/2009JPO4236.1.

McIntosh, P. C., and S. R. Rintoul (1997), Do box inverse models work?, J. Phys. Oceanogr., 27, 291-308.

Mensch, M., R. Bayer, J. Bullister, P. Schlosser, and R. Weiss (1996), The distribution of tritium and CFCs in the Weddell Sea during the mid1980s, Prog. Oceanogr., 38(4), 377-415.

Meredith, M. (2010), Cruise report, RRS James Clark Ross, Tech. Rep. jr235/236/239, Br. Antarct. Surv., Cambridge, U. K.

Meredith, M., R. Locarnini, K. V. Scoy, A. Watson, K. Heywood, and B. King (2000), On the sources of Weddell Gyre Antarctic Bottom Water, J. Geophys. Res., 105(C1), 1093-1104.

Meredith, M. P., A. Watson, and K. V. Scoy (2001), Chlorofluorocarbon-derived formation rates of the deep and bottom waters of the Wed dell Sea, J. Geophys. Res., 106(C2), 2899-2919.

Naveira Garabato, A. C., E. McDonagh, D. P. Stevens, K. J. Heywood, and R. J. Sanders (2002a), On the export of Antarctic bottom water from the Weddell Sea, Deep Sea Res., Part II, 49, 4715-4742.

Naveira Garabato, A. C., K. J. Heywood, and D. P. Stevens (2002b), Modification and pathways of Southern Ocean deep waters in the Scotia Sea, Deep Sea Res., Part I, 49(4), 681-705.

Naveira Garabato, A. C., A. Williams, and S. Bacon (2013), The three-dimensional overturning circulation of the Southern Ocean during the WOCE era, Prog. Oceanogr., 120, 41-78, doi:10.1016/j.pocean.2013.07.018.

Nicholls, K. W., S. Østerhus, K. Makinson, T. Gammelsrød, and E. Fahrbach (2009), Ice-ocean processes over the continental shelf of the southern Weddell Sea, Antarctica: A review, Rev. Geophys., 47, RG3003, doi:10.1029/2007RG000250.

Ohshima, K. l., et al. (2013), Antarctic Bottom Water production by intense sea-ice formation in the Cape Darnley polynya, Nat. Geosci., 6(3), 235-240.

Orsi, A., and T. Whitworth (1993), On the circulation and stratification of the Weddell Gyre, Deep Sea Res., Part l, 40, $169-203$.

Orsi, A. H., G. C. Johnson, and J. L. Bullister (1999), Circulation, mixing, and production of Antarctic Bottom Water, Prog. Oceanogr., 43(1), 55-109.

Orsi, A. H., W. M. Smethie Jr., and J. L. Bullister (2002), On the total input of Antarctic Waters to the deep ocean: A preliminary estimate from chlorofluorocarbon measurements, J. Geophys. Res., 107(C8), 3122, doi:10.1029/2001JC000976.

Park, Y.-H., E. Charriaud, P. Craneguy, and A. Kartavtseff (2001), Fronts, transport, and Weddell Gyre at $30^{\circ}$ E between Africa and Antarctica, J. Geophys. Res., 106(C2), 2857-2879.

Petty, A. A., P. R. Holland, and D. L. Feltham (2013), Sea ice and the ocean mixed layer over the Antarctic shelf seas, Cryosphere, 7(4), 43214377.

Rignot, E., J. L. Bamber, M. R. van den Broeke, C. Davis, Y. Li, W. J. V. D. Berg, and E. V. Meijgaard (2008), Recent Antarctic ice mass loss from radar interferometry and regional climate modelling, Nat. Geosci., 1(2), 106-110, doi:10.1038/ngeo102.

Rintoul, S., and A. C. Naveira Garabato (2013), Dynamics of the Southern Ocean circulation, in Ocean Circulation and Climate: A 21st Century Perspective, International Geophysics Ser., vol. 103, edited by J. G. G. Siedler et al., pp. 471-492, Elsevier, N. Y.

Schodlok, M., H. H. Hellmer, and A. Beckmann (2002), On the transport, variability and origin of dense water masses crossing the South Scotia ridge, Deep Sea Res., Part II, 49(21), 4807-4825.

Schröder, M., and E. Fahrbach (1999), On the structure and the transport of the eastern Weddell Gyre, Deep Sea Res., Part II, 46, 501-527.

Sloyan, B. M., and S. R. Rintoul (2000), Estimates of area-averaged diapycnal fluxes from basin-scale budgets, J. Phys. Oceanogr., 30, 23202349.

Sloyan, B. M., and S. R. Rintoul (2001), The Southern Ocean limb of the global deep overturning circulation, J. Phys. Oceanogr., $31,143-173$. Speer, K. G., and T. Dittmar (2008), Cruise report, RV Revelle, Tech. Rep. 33rr20080204, Fla. State Univ., Tallahassee, Fla.

Speer, K. G., S. R. Rintoul, and B. M. Sloyan (2000), The diabatic Deacon cell, J. Phys. Oceanogr., 30(12), 3212-3222. 
Sverdrup, H. (1947), Wind-driven currents in a baroclinic ocean; with application to the equatorial currents of the eastern Pacific, Proc. Natl. Acad. Sci. U. S. A., 33(11), 318-326, doi:10.1073/pnas.33.11.318.

Talley, L. D. (2013), Closure of the global overturning circulation through the Indian, Pacific, and Southern Oceans: Schematics and transports, Oceanography, 26(1), 80-97.

Tanhua, T., S. van Heuven, R. M. Key, A. Velo, A. Olsen, and C. Schirnick (2010), Quality control procedures and methods of the CARINA database, Earth Syst. Sci. Data, 2(1), 35-49, doi:10.5194/essd-2-35-2010.

Thompson, A. F., and K. J. Heywood (2008), Frontal structure and transport in the northwestern Weddell Sea, Deep Sea Res., Part l, 55(10), $1229-1251$.

Thompson, A. F., K. J. Heywood, S. E. Thorpe, A. H. H. Renner, and A. Trasviña (2009), Surface circulation at the tip of the Antarctic Peninsula from drifters, J. Phys. Oceanogr., 39(1), 3-26.

Tsubouchi, T., S. Bacon, A. C. Naveira Garabato, Y. Aksenov, S. W. Laxon, E. Fahrbach, A. Beszczynska-Möller, E. Hansen, C. M. Lee, and R. B. Ingvaldsen (2012), The Arctic Ocean in summer: A quasi-synoptic inverse estimate of boundary fluxes and water mass transformation, $J$. Geophys. Res., 117, C01024, doi:10.1029/2011JC007174.

Wang, Q., S. Danilov, and J. Schröter (2009), Bottom water formation in the southern Weddell sea and the influence of submarine ridges: Idealized numerical simulations, Ocean Modell., 28(1-3), 50-59, doi:10.1016/j.ocemod.2008.08.003.

Whitworth, T., W. D. Nowlin, A. H. Orsi, R. A. Locarnini, and S. G. Smith (1994), Weddell Sea shelf water in the Bransfield Strait and WeddellScotia confluence, Deep Sea Res., Part I, 41, 629-636.

Worby, A. P., C. Geiger, M. J. Paget, M. van Woert, S. F. Ackley, and T. DeLiberty (2008), Thickness distribution of Antarctic sea ice, J. Geophys. Res., 113, C05S92, doi:10.1029/2007JC004254.

Wunsch, C. (1996), The Ocean Inverse Circulation Inverse Problem, 442 pp., Cambridge Univ. Press, Cambridge, U. K.

Yaremchuk, M., D. Nechaev, J. Schroter, and E. Fahrbach (1998), A dynamically consistent analysis of circulation and transports in the southwestern Weddell Sea, Ann. Geophys., 16(8), 1024-1038. 